Maidens," which is simply an abbreviation for Nineteen Maidens.

The following quotation from Diodorus Siculus (Book II. chap. iii. Booth's Trans, page 139), who flourished about forty-four years B.C., will be an historical confirmation of what I have above stated :- -

"Amongst those who have written old stories much like fables, Hecatæus (born 549 years B.c.) and some others say that there is an island in the ocean over against Gaul (as big as Sicily) under the Arctic pole, where the Hyperboreans inhabit, so called because they lie beyond the breezes of the north wind; that the soil there is very rich and fruitful, and the climate temperate, inasmuch as there are two crops in the year."

This description does not apply to the whole of the island referred to, but represents Mount's Bay, its most south-western extremity, and we may therefore conclude that those from whom Hecatæus and the others derived their information were the Phœenician traders who for centuries previously frequented Mount's Bay for tin and fish, and who imagined all Britain to possess the same rich soil and mild climate as Mount's Bay where still " there are two crops in the year." But to proceed with the quotation :-

"They say that Latona was born there, that they worship Apollo above all other gods, and the inhabitants demean themselves as if they were Apollo's priests, who has there a stately grove and a renowned temple of a round form, and that there is a city likewise consecrated to this god. The sovereignty of this city and the care of the temple (they say) belong to the Boreades.'

This city and this " renowned temple of a round form" are doubtless those of Old Sarum and Stonehenge, the inner oval of which, immediately around the altar, consists of precisely nineteen stones (see the plate in Dr. Stukeley's "Stonehenge," page 20). But the four temples of the sun above described of nineteen stones each, placed upright "in a round form" to represent the cycle of nineteen years, are not mentioned by Diodorus, as they were probably deemed not worthy of notice after alluding to the renowned temple of Stonehenge. The passage concludes as follows :-

"They say, moreover, that Apollo once in nineteen years comes into the island, in which space of time the stars perform their courses, and return to the same point, and therefore the Greeks call the revolution of nineteen years 'the great year."

Plymouth, August

R. EDMONDS

\section{Nebula in Andromeda}

LAST night the nebula in Andromeda was observed here, The stellar-like nucleus was distinctly seen. It appeared to be of a reddish-yellow colour as contrasted with that of the nebula. We think that a change has certainly taken place, no such stellar-like centre having previously been seen in the nucleus. The stellar point was examined with a small prism held between the eye-piece and the eye. A continuous spectrum was seen. Dr. Boeddicher and I were both convinced that there were considerable inequalities in its light, and independently formed the impression that there was at times a bright band or line in the green. The colour of the stellar point appeared much the same as that of Aldebaran.

Observatory, Birr Castle, September 8

\section{Sunsets}

IN July of this year I spent a short time in the Schwarzwald of Baden. For more than a week the sky was cloudless day and night, yet the heat was not oppressive. The sunsets were beautiful beyond description, and the after-glows magnificent. One evening in particular will always remain impressed upon my memory. It was that of July 26 , and the place was a few miles from the town of Neustadt, nearly in the centre of the forest. Wonderful effects began to appear so soon as the sun touched the crest of the western hills. But these were as nothing compared with what followed. The moment the luminary had disappeared behind the hills long streamers began to radiate high up into the heavens, and for a time, as the daylight diminished, they increased both in length and intensity, rivalling any description or figures of the Arc'ic auroras that I have ever seen ; at the same time the most vivid and ever-changing glow lit up the whole western heavens. The scene lasted more than an hour, and its effect was heightened by, and perhaps partly due to, a nearly full moon, which rose from behind a slight dip or pass in the hills on the eastern side of the valley. The inhabitants of the Schwarzwald are indubitably phlegmatic, and not easily moved to excitement; but this display of celestial pyrotechnics was too much for them, and at a small roadside inn the carters and others who were enjoying their beer inside turned out en masse to witness it. I am not a strong admirer of Turner's pictures, but, in comparing nature with art, one idea came uppermost-the scene was "Turneresque."

Lewisham, S.E., September 3

R. MCLachlan

\section{Pulsation in the Veins}

Mr. Hippisley will find a very simple way of showing pulsation in the veins, as well as in the arteries, by fixing a long bristle or thread of sealing-wax over the vessel by means of a little tallow. The end of the lever will vibrate and produce all the movements of the sphygmograph. This method was adopted by Mr. Wilkinson King nearly fifty years ago, and the instrument styled by him the sphygmometer. In his paper in the Guy's Hospital Reports for 1837, "On the Safety Valve Function of the Right Ventricle of the Heart," will be found much valuable matter and discussion about venous pulsation.

August 29

S. W.

\section{Red Hail}

VU l'intérêt que peut offrir la coloration de la grêle, j'espère que vous voudrez bien insérer ces quelques lignes dans votre journal : "La grêle colorée en rouge, observée par Mr. Mullan et dont il est question dans Ie No. 812 de ce journal, n'est pas un fait isolé. On a observé un cas analogue en 1880 , le $\frac{2}{14}$ juin, en Russie. Les grêlons de cette chute-là étaient intéressants sous plus d'un rapport. Leur forme se ramenait à trois types: parallélipipède, cylindre, sphéroïde très-aplati et muni de cavité aux bouts de la petite axe. Certains de ces grêlons étaient percés de part en part, le long de la petite axe, ce qui leur donnait l'apparence des anneaux. Certains des grêlons étaient colorés en rouge-pâle, d'autres avaient la couleur bleu-pâle, mais pour la plupart les grêlons étaient gris ou blanc. L'observateur, M. Lagounowitch, crut avoir remarqué que la couleur était liée à la forme des grêlons. Je cite ces faits et j'en propose l'explication dans ma brochure, "Sur l'Origine de la Grêle."

THÉODORE SCHWEDOFF, Professeur de Physique à l'Université d'Odessa Odessa, le $\frac{15}{27}$ août, 1885

\section{On the Terminology of the Mathematical Theory of Electricity}

Mr. Sutherland's letter on terminology (Nature, vol. xxxii. p. 39r) leads me to suggest to $\mathrm{Mr}$. Scott the employment of the term loze-pression for depression in his weather forecasts sent to the newspapers. It is nearly as easily pronounced and written, and will not have such a tendency to mislead the general public as to there being a depressing of the air where it really ascends.

Cambuslang Henry Muirhead

\section{THE BRITISH ASSOCIATION}

\section{Aberdeen, Monday}

THIS place has evidently been astir for days in anticipation of the present meeting. Already are the directions necessary for visitors finding their way to the various sections put up in conspicuous places in Union Street and the neighbourhood of Marischal College. The accommodation in the fine building for reception rooms, committee rooms, reading, sectional, and other rooms, seems, so far as can be judged at present, everything that could be desired. It is evident that the Local Committee have been working in earnest to make the second Aberdeen meeting a success, and their efforts have been heartily supported by the citizens and country people. Up to Saturday 1000l. worth of tickets had been sold to local people alone, and many more will be sold between this and Wednesday. Of old members of the Association 750 have already written that they intend to be present 
and it is confidently anticipated that quite 2500 people will take out tickets for the meeting. This great influx of strangers has tasked the available accommodation in Aberdeen, and, as might be expected, the charges in hotels and lodging-houses are somewhat exorbitant.

Of foreigners who are to be present one of the most distinguished is Prof. O.C. Marsh, the well-known American palæontologist, who. it is expected, will take part in the proceedings of both $\mathrm{C}$ and $\mathrm{D}$. Others are the Abbé Renard of Brussels, Dr, Max Schuster of Vienna, Dr. von Dechen of Bonn, and Prof. Radlkofer of Munich. It is expected that Mr. Im Thurn, the naturalist, who recently ascended Mount Roraima in British Guiana, will be able to be here, and tell personally of his ascent and its important results.

Of the excursions, that to Balmoral on Saturday is evidently the favourite, and there will be considerable competition to be included among the i 5o. The Earl of Crawford has for the same day invited sixty members to visit Dunecht, where the observatory will be inspected, and where the archæologists will be shown the "Barnekin of Dunecht." The Earl of Crawford also contributed several very valuable and interesting objects to a fine exhibition of antiquities, old books and manuscripts, that is being arranged. Among the expeditions arranged for Thursday the I7th, is one specially for geologists, to Portsoy; and for the same day the Rev. W. Gordon invites a party of naturalists to Braemar.

Among the local establishments which will be open to the inspection of visitors are several of the great granite works for which Aberdeen is so famous.

Another exhibition of special interest, arranged by the Scottish Geographical Society, will consist of Scottish maps, including some I 50 different maps, atlases, guides, and special topographical works.

If one may judge from the present appearance of the weather, the meteorological conditions promise to be favourable, and, if so, the meeting will be sure to be successful, so far as pleasuring is concerned, while the discussions that have been arranged for the Sections A and $\mathrm{B}$ are likely to give it considerable scientific importance.

InaUgurat Address by the Right Hon. Sir Lyon Playfair, K.C.B., M.P., F.R.S., President

I. Visit to Canada.-Our last meeting at Montreal was a notable event in the life of the British Association, and even marked a distinct epoch in the history of civilisation. It was by no mere accident that the constitution of the Association enabled it to embrace all parts of the British Empire. Science is truly catholic, and is bounded only by the universe. In relation to our vast empire, science, as well as literature and art, are the common possession of all its varying people. The United Kingdom is limited to 120,800 square miles, inhabited by 35 millions of people; but the empire as a whole has $8 \frac{1}{2}$ millions of square miles, with a population of 305 millions. To federate such vast possessions and so teeming a population into a political unit is a work only to be accomplished by the labours and persistent efforts of perhaps several generations of statesmen. The federation of its science is a subject of less dimensions well within the range of experiment. No part of the British Empire was more suited than Canada to try whether her science could be federated with our science. Canada has lately federated distinct provinces, with conflicting interests arising from difference of races, nationalities, and religions. Political federation is not new in the history of the world, though it generally arises as a consequence of war. It was war that taught the Netherlands to federate in 1619. It was war which united the States in America ; federated Switzerland, Germany, and Austria, and unified Italy. But Canada formed a great national life out of petty provincial existences in a time of profound peace. This evolution gave an immense impulse to her national resources. The Dominion still requires consolidation in its vast extent, and applied science is rapidly effecting it. Canada, with its great expanse of territory, nearly as large as the United States, is being lnit together by the iron bands of railways from the Gulf of St. Lawrence to the Pacific Ocean, so that the fertile lands of Ontario, Manitoba, Columbia, and the North-Western territories will soon be available to the world. Still practical science has much to accomplish. England and France, with only onefifth the fertile area of Canada, support 80 millions of people, while Canada has a population not exceeding 5 millions.

A less far-seeing people than the Canadians might have invited the applied science which they so much require. But they knew that without science there are no applications. They no doubt felt with Emerson-

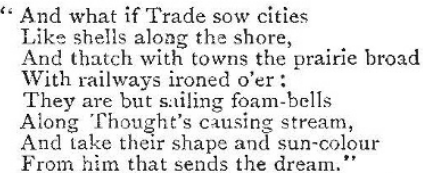

So it was with a far-reaching foresight that the Canadian Government invited the British Association for the Advancement of Science to meet in Montreal. The inhabitants of Canada received us with open arms, and the science of the Dominion and that of the United Kingdom were welded. We found in Canada, as we had every reason to expect, men of manly and self-reliant character, who loved not less than we did the old home from which they had come. Among them is the same healthiness of political and moral life, with the same love of truth which distinguishes the English people. Our great men are their great men : our Shakspeare, Milton, and Burns belong to them as much as to ourselves; our Newton, Dalton, Faraday, and Darwin are their men of science as much as they are ours. Thus a common possession and mutual sympathy made the meeting in Canada a successful effort to stimulate the progress of science, while it established, at the same time, the principle that all people of British origin-and I would fain include our cousins in the United States-possess a common interest in the intellectual glories of their race, and ought, in science at least, to constitute part and parcel of a common empire, whose heart may beat in the small islands of the northern seas, but whose blood circulates in all her limbs, carrying warmth to them and bringing back vigour to us. Nothing can be more cheering to our Association than to know that many of the young communities of English-speaking people all over the globe-in India, China, Japan, the Straits, Ceylon, Australia, New Zealand, the Capehave founded scientific societies in order to promote the growth of scientific research. No doubt science, which is only a form of truth, is one in all lands, but still its unity of purpose and fulfilment received an important practical expression by our visit to Canada. This community of science will be continued by the fact that we have invited Sir William Dawson, of Montreal, to be our next President at Birmingham.

II. Science and the State. - I cannot address you in Aberdeen without recollecting that when we last met in this city our President was a great prince. The just verdict of time is that, high as was his royal rank, he has a far nobler claim to our regard as a lover of humanity in its widest sense, and especially as a lover of those arts and sciences which do so much to adorn it. On September 14, I859, I sat on this platform and listened to the eloquent address and wise counsel of the Prince Consort. At one time a member of his household, it was my privilege to co-operate with this illustrious prince in many questions relating to the advancement of science. I naturally, therefore, turned to his presidential address to see whether I might not now continue those counsels which he then gave with all the breadth and comprehensiveness of his masterly speeches. I found, as I expected, a text for my own discourse in some pregnant remarks which he made upon the relation of science to the State. They are as follows :- "We may be justinied in hoping . . . that the Legislature and the State will more and more recognise the claims of science to their attention, so that it may no longer require the begging-box, but speak to the State like a favoured child to its parent, sure of his paternal solicitude for its welfare; that the State will recognise in science one of its elements of strength and prosperity, to foster which the clearest dictates of self-interest demand."

This opinion, in its broadest sense, means that the relations of science to the State should be made more intimate because the advance of science is needful to the public weal.

The importance of promoting science as a duty of statecraft was well enough known to the ancients, especially to the Greeks and Arabs, but it ceased to be recognised in the dark ages, and 
was lost to sight during the revival of letters in the fifteenth and sixteenth centuries. Germany and France, which are now in such active competition in promoting science, have only publicly acknowledged its national importance in recent times. Even in the last century, though France had its Lavoisier and Germany its Leibnitz, their Governments did not know the value of science. When the former was condemned to death in the Reign of Terror, a petition was presented to the rulers that his life might be spared for a few weeks in order that he might complete some important experiments, but the reply was, "The Republic has no need of savants." Earlier in the century the much-praised Frederick William of Prussia shouted with a loud voice, during a graduation ceremony in the University of Frankfort, "An ounce of mother-wit is worth a ton of university wisdom." Both France and Germany are now ashamed of these utterances of their rulers, and make energetic efforts to advance science with the aid of their national resources. More remarkable is it to see a young nation like the United States reserving $150,000,000$ acres of national lands for the promotion of scientific education. In some respects this young country is in advance of all European nations in joining science to its administrative offices. Its scientific publications, like the great palrontclogical work embodying the researches of Prof. Marsh and his associates in the Geological Survey, are an example to other Governments. The Minister of Agriculture is surrounded with a staff of botanists and chemists. The Home Secretary is aided by a special Scientific Commission to investigate the habits, migrations, and food of fishes, and the latter has at its disposal two specially-constructed steamers of large tonnage. The United States and Great Britain promote fisheries on distinct systems. In this country we are perpetually issuing expensive Commissions to visit the coasts in order to ascertain the experiences of fishermen. I have acted as chairman of one of these Royal Commissions, and found that the fishermen, having only a knowledge of a small area, gave the most contradictory and unsatisfactory evidence. In America the questions are put to Nature, and not to fishermen. Exact and searching investigations are made into the life-history of the fishes, into the temperature of the sea in which they live and spawn, into the nature of their food, and into the habits of their natural enemies. For this purpose the Government give the co-operation of the navy, and provide the Commission with a special corps of skilled naturalists, some of whom go nut with the steamships and others work in the biological laboratories at Wood's Holl, Massachusetts, or at Washington. The different universities send their best naturalists to aid in these investigations, which are under the direction of Mr. Baird, of the Smithsonian Institution. The annual cost of the Federal Commission is about 40,000 l., while the separate States spend about 20,000 l. in local efforts. The practical results flowing from these scientific investigations have been important. The inland waters and rivers have been stocked with fish of the best and most suitable kinds. Even the great ocean which washes the coasts of the United States is beginning to be affected by the knowledge thus acquired, and a sensible result is already produced upon the most important of its fi:heries. The United Kingdom largely depends upon its fisheries, but as yet our own Government have scarcely realised the value of such scientific investigations as those pursued with success by the United States. Less systematically, but with great benefit to science, our own Government has used the surveying expeditions, and sometimes has equipped special expeditions to promote natural history and solar physics. Some of the latter, like the voyage of the Challenger, have added largely to the store of knowledge; while the former, though not primarily intended for scientific research, have had an in direct result of infinite value by becoming training-schools for such investigators as Edward Forbes, Darwin, Hooker, Huxley, Wyville Thomson, and others.

In the United Kingdom we are just beginning to understand the wisdom of Washington's farewell address to his countrymen when he said : "Promote as an object of primary importance institutions for the general diffusion of knowledge. In proportion as the structure of a government gives force to public opinion, it is essential that public opinion should be enlightened." It was only in I870 that our Parliament established a system of national primary education. Secondary education is chaotic, and remains unconnected with the State, while the higher education of the universities is only brought at distant intervals under the view of the State. All great countries except England have Ministers of Education, but this country has only Ministers who are the managers of primary schools. We are inferior even to smaller countries in the absence of organised State supervision of education. Greece, Portugal, Egypt, and Japan have distinct Ministers of Education, and so also among our Colonies have Victoria and New Zealand. Gradually England is gathering materials for the establishment of an efficient Education Minister. The Department of Science and Art is doing excellent work in diffusing a taste for elementary science among the working classes. There are now about 78,000 persons who annully come under the influence of its science classes, while a small number of about 200 , many of them teachers, receive thorough instruction in science at the excellent school in South Kensington, of which Prof. Huxley is the Dean. I do not dwell on the work of this Government department, because my object is chiefly to point out how it is that science lags in its progress in the United Kingdom owing to the deficient interest taken in it by the middle and upper classes. The working classes are being roused from their indifference. They show this by their selection of scientific men as candidates at the next election. Among these are Profs. Stuart, Roscoe, Maskelyne, and Ruicker. It has its significance that such a humble representative of science as myself received invitations from working-class constituencies in more than a dozen of the leading manufacturing towns. In the next Parliament $I$ do not doubt that a Minister of Education will becreated as ${ }^{\circ}$ nucleus around which the various educational materials may crystallise in a definite form.

III. Science and Secondary Education. - Various Royal Commissions have made inquiries and issued recommendations in regard to our public and endowed schools. The Commissions of $1861,1864,1868$, and 1873 have expressed the strongest disapproval of the condition of our schools, and, so far as science is concerned, their state is much the same as when the Duke of Devonshire's Commission in 1873 reported in the following words :- "Considering the increasing importance of science to the material interests of the country, we cannot but regard its almost total exclusion from the training of the upper and middle classes as little less than a national misfortune." No doubt there are exceptional cases and some brilliant examples of improvement since these words were written, but generally throughout the country teaching in science is a name rather than a reality. The Technical Commission which reported last year can only point to three schools in Great Britain in which science is fully and adequately taught. While the Commission gives us the consolation that England is still in advance as an industrial nation, it warns us that foreign nations, which were not long ago far behind, are now making more rapid progress than this country, and will soon pass it in the race of competition unless we give increased attention to science in public education. A few of the large towns, notably Manchester, Bradford, Huddersfield, and Birmingham, are doing so. The working classes are now receiving better instruction in science than the middle classes. The competition of actual life asserts its own conditions, for the children of the Iatter find increasing difficulty in obtaining employment. The cause of this lies in the fact that the schools for the middle classes have not yet adapted themselves to the needs of modern life. It is true that many of the endowed schools have been put under new schemes, but as there is no public supervision or inspection of them, we have no knowledge as to whether they have prospered or slipped back. Many corporate schools have arisen, some of them, like Clifton, Cheltenham, and Marlborough Colleges, doing excellent educational work, though as regards all of them the public have no rights and cannot enforce guarantees for efficiency. A return just issued, on the motion of Sir John Lubbock, shows a lamentable deficiency in science teaching in a great proportion of the endowed schools. While twelve to sixteen hours a week are devoted to classics, two to three hours are considered ample for science in a large proportion of the schools. In Scotland there are only six schools in the Return which give more than two hours to science weekly, while in many schools its teaching is wholly omitted. Every other part of the kingdom stands in a better position than Scotland in relation to the science of its endowed schools. The old traditions of education stick as firmly to schools as a limpet does to a rock; though I do the limpet injustice, for it does make excursions to seek pastures new. Are we to give up in despair because an exclusive system of classical education has resisted the assaults of such cultivated authors as Milton, Montaigne, Cowley, and Locke? There was once an enlightened Emperor of China, Chi Hwangti, who knew that his country waskept back by its exclusive devotion to the classic 
of Confucius and Mencius. He invited 500 of the tcachers to bring their copies of these authors to Pekin, and after giving a great banquet in their honour, he buried alive the professors along with their manuscripts in a deep pit. But Confucius and Mencius still reign supreme. I advocate milder measures, and depend for their adoption on the force of public opinion. The needs of modern life will force schools to adapt themselves to a scientific age. Grammar-schools believe themselves to be immortal. Those curious immortals - the Struldburgs-described by Swift, ultimately regretted their immortality, because they found themselves out of touch, sympathy, and fitness with the centuries in which they lived.

As there is no use clamouring for an instrument of more compass and power until we have made up our minds as to the tune, Prof. Huxley, in his evilence before a Parliamentary Committee in 1884, has given a time-table for grammar-schools. He demands that out of their forty hours for public and private study, ten should be given to modern languages and history, eight to arithmetic and mathematics, six to science, and two to geography, thus leaving fourteen hours to the dead languages. No time-table would, however, be suitable to all schools. The great public schools of England will continue to be the gymnasia for the upper classes, and should devote much of their time to classical and literary culture. Even now they introduce into their curriculum subjects unknown to them when the Royal Commission of $\mathbf{I} 868$ reported, thongh they still accept science with timidity. Unfortunately the other grammar-schools which educate the middle classes look to the higher public schools as a type to which they should conform, although their functions are so different. It is in the interest of the higher public schools that this difference should be recognised, so that, while they give an all-round education and expand their curriculum by a freer recognition of the value of science as an educational power in developing the faculties of the upper classes, the schools for the middle classes should adapt themselves to the needs of their existence, and not keep up a slavish imitation of schools with a different function. The old classical grammar-schools may view these remarks as a direct attack upon them, and so it is in one sense, but it is like the stroke of Ithuriel's spear, which heals while it wounds.

The stock argument against the introduction of modern subjects into grammar schools is that it is better to teach Latin and Greek thoroughly rather than various subjects less completely. But is it true that thoroughness in teaching dead languages is the result of an exclusive system? In 1868 the Royal Commission stated that even in the few great public schools thoroughness was only given to 30 per cent. of the scholars, at the sacrifice of 70 per cent. who got little benefit from the system. Since then the curriculum has been widened and the teaching has improved. I question the soundness of the principle that it is better to limit the attention of the pupils mainly to Latin and Greek, higbly as I value their educational power to a certain order of minds. As in biology the bodily development of animals is from the general to the special, so is it in the mental development of man. In the school a boy shauld be aided to discover the class of knowledge that is best suited for his mental capacities, so that, in the upper forms of the school and in the university, knowledge may be specialised in order to cultivate the powers of the man to their fullest extent. Shakspeare's educational formula may not be altogether true, but it contains a broad basis of truth-

$$
\begin{aligned}
& \text { "No profit goes, where is no pleasure ta'en;-- } \\
& \text { In brief, sir, study what you most affect." }
\end{aligned}
$$

The comparative failure of the modern side of school education arises frum constituting it out of the boys who are looked upon as classical asses. Milton pointed out that in all schools there are boys to whom the dead languages are "like thorns and thistles," which form a poor nourishment even for asses. If teachers looked upon these classical asses as beings who might receive mental nurture according to therr nature, much higher results would follow the bifurcation of our schools. Saul went out to look for asses and he found a kingdom. Surely this fact is more encouraging than the example of Gideon, who "took thorns of the wilderness and briars, and with these he taught the men of Succoth." 1 The adaptation of public schools to a scientific age does not involve a contest as to whether science or classics shall prevail, for both are indispensable to true education. The real question $\mathrm{i}$ : whether schools will undertake the duty of moulding the minds of boys according to their mental varieties. Classics,

$$
1 \text { Judges, viii. } x 6 \text {. }
$$

from their structural perfection and power of awakening dormant faculties, have claims to precedence in education, but they have none to a practical monopoly. It is by claiming the latter that teachers sacrifice mental receptivity to a Procrustean uniformity.

The universities are changing their traditions more rapidly than the schools. The via antiqua which leads to them is still broad, though a via moderna, with branching avenues, is also open to their honours and emoluments. Physical science, which was once neglected, is now encouraged at the universities. As to the 70 per cent. of boys who leave schools for life-work without going through the universities, are there no growing signs of discontent which must force a change? The Civil Service, the learned professions, as well as the army and navy, are now barred by examinations. Do the boys of our public schools easily leap over the bars, although some of them have lately been lowered so as to suit the schools? So difficult are these bars to scholars that crammers take them in hand before they attempt the leap; and this occurs in spite of the large value attached to the dead languages and the small value placed on modern subjects. Thus, in the Indian Civil Service examinations, 800 marks as a maximum are assigned to Latin, 600 to Greek, 500 to chemistry, and 300 to each of the other physical sciences. But if we take the average working of the system for the last four years we find that while 68 per cent. of ithe maximum were given to candidates in Greek and Latin, only 45 per cent. were accorded to candidates in chemistry, and but 30 per cent. to the otker physical sciences. Schools sending up boys for competition naturally shun subjects which are dealt with so hardly and so heavily handicapped by the State.

Passing from learned or public professions to commerce, how is it that in our great commercial centres, foreigners-German, Swiss, Dutch, and even Greeks-push aside our English youth and take the places of profit which belong to them by national inheritance? How is it that in our colonies, like those in South Africa, German enterprise is pushing aside English incapacity? How is it that we find whole branches of manu. factures, when they depend on scientific knowledge, passing away from this country, in which they originated, in order to engraft themselves abroad, although their decaying roots remain at home ? ${ }^{1}$ The answer to these questions is that our systems of education are still too narrow for the increasing struggle of life.

Faraday, who had no narrow views in regard to education, deplored the future of our youth in the competition of the world, because, as he said with sadness, "our schoolboys, when they come out of school, are ignorant of their ignorance at the end of all that education."

The opponents of science education allege that it is not adapted for mental development, because scientific facts are often disjointed and exercise only the memory. Those who argue thus do not know what science is. No doubt an ignorant or half-informed teacher may present science as an accumulation of unconnected facts. At all times and in all subjects there are teachers without æesthetical or philosophical capacity-men who can only see carbonate of lime in a statue by Phidias or Praxiteles; who cannot survey zoology on account of its millions of species, or botany because of its 130,000 distinct plants; men who can look at trees without getting a conception of a forest, and cannot distinguish a stately edifice from its bricks. To teach in that fashion is like going to the tree of science with its glorious fruit in order to pick up a handful of the dry fallen leaves from the ground. It is, however, true that as science teaching has had less lengthened experience than that of literature, its methods of instruction are not so matured. Scientific and literary teaching have different methods; for while the teacher of literature rests on authority and on books for his guidance, the teacher of science discards authority and depends on facts at first hand, and on the book of Nature for their interpretation. Natural science more and more resolves itself into the teaching of the laboratory. In this way it can be used as a powerful means of quickening observation, and of creating a faculty of induction after the manner of Zadig, the Babylonian described by Voltaire. Thus facts become surrounded by scientific conceptions, and are subordinated to order and law.

It is not those who desire to unite literature with science who degrade education; the degradation is the consequence of the refusal. A violent reaction-too violent to be wise-has lately

1 See Dr. Perkins's addres; to the Soc. Chem. Industry, Nature August 6, 1855, p. 333 
taken place against classical education in France, where their own vernacular occupies the position of dead languages, while I.atin and science are given the same time in the curriculum. In England manufacturers cry out for technical education, in which classicul culture shall be excluded. In the schools of the middle classes science rather than technics is needed, because, when the seeds of science are sown, technics as its fruit will appear at the appointed time. Epictetus was wise when he told us to observe that, though sheep eat grass, it is not grass but wool that grows on their backs. Should, however, our grammarschools persist in their refusal to adapt themselves to the needs of a scientific age, England must follow the example of other European nations and found new modern schools in competition with them. For, as Huxley has put it, we cannot continue in this age " of full modern artillery to turn ont our boys to do battle in it, equipped only with the sword and shield of an ancient gladiator." In a scientific and keenly competitive age an exclusive education in the dead languages is a perplexing anomaly. The flowers of literature should be cultivated and gathered, though it is not wise to send men into our fields of industry to gather the harvest when they have been taught only to cull the poppies and to push aside the wheat.

IV. Science and the Universities. - The State has always felt bound to alter and improve universities, even when their endowments are so large as to render it unnecessary to support them by public funds. When universities are poor, Parliament gives aid to them from imperial taxation. In this country that aid has been given with a very sparing hand. Thus the universities and colleges of Ireland have received about $30,000 l$. annually, and the same sum has been granted to the four universities of Scotland. Compared with imperial aid to foreign universities such sums are small. A single German university like Strassburg or Leipsic receives about $40,000 l$. annually, or I0,00ol. more than the whole colleges of Ireland or of Scotland. Strassburg, for instance, has had her university and its library rebuilt at a cost of $711,000 l$, , and receives an annual subscription of $43,000 l$. In rebuilding the University of Strassburg eight laboratories have been provided, so as to equip it fully with the modern requirements for teaching and research. ${ }^{1}$ Prussia, the most economical nation in the world, spends 391, 00ol. yearly out of taxation on her universities.

The recent action of France is still more remarkable. After the Franco-German war the Institute of France discussed the important question: “Pourquoi la France n'a pas trouvé d'hommes supérieurs au moment du péril ?" The general answer was, Because France had allowed university education to sink to a low ebb. Before the great Revolution France had twenty-three autonomous universities in the provinces. Napoleon desired to found one great university at Paris, and he crushed out the others with the hand of a despot, and remodelled the last with the instincts of a drill-sergeant. The central university sank so low than in 1868 it is said that only $8000 l$. were spent for true academic purposes. Startled by the intellectual sterility shown in the war, France has made gigantic efforts to retrieve her position, and has rebuilt the provincial colleges at a cost of $3,280,000$., while her annual budget for their support now reaches half a million of pounds. In order to open these provincial colleges to the best talent of France, more than 500 scholarships have been founded at an annual cost of $30,000 l$. France now recognises that it is not by the number of men under arms that she can compete with her great neighbour Germany, so she has determined to equal her in intellect. You will understand why it is that Germany was obliged, even if she had not been willing, to spend such large sums in order to equip the university of her conquered province, Alsace-Lorraine. France and Germany are fully aware that science is the source of wealth and power, and that the only way of advancing it is to encourage universities to make researches and to spread existing knowledge through the community. Other European nations are advancing on the same lines. Switzerland is a remarkable illustration of how a country can compensate itself for its natural di-advantages by a scientific education of its people. Switzerland contains neither coal nor the ordinary raw materials of industry, and is separated from other countries which might supply them by mountain barriers. Yet, by a singularly good system of graded schools, and by the

I The cost of these laboratories has been as follows :-Chemical Institute, 35, 000 l. ; Physical Institute, 28,000l.; Botanical Institute, 26,000l.; Observatory, 25,000l. ; Anatomy. 42,000l.; Clinical Surgery, 26,00ol. ; Physiological Chemistry, $16,000 l$.; Physiological Institute, $13,900 l$. great technical college of Zurich, she has become a prosperous manufacturing country. In Great Britain we have nothing comparable to this technical college, either in magnitude or efficiency. Belgium is reorganising its universities, and the State has freed the localities from the charge of buildings, and will in future equip the universities with efficient teaching resources out of public taxation. Holland, with a population of 4,000,000 and a small revenue of $9,000,000 t$., spends $136,000 l$. on her four universities. Contrast this liberality of foreign countries in the promotion of higher instruction with the action of our own country. Scotland, like Holland, has four universities, and is not very different from it in population, but it only receives 30,000l. from the State. By a special clause in the Scotch Universities Bill the Government asked Parliament to declare that under no circumstances should the Parliamentary grant be ever increased above $40,000 \%$. According to the views of the British Treasury there is a finality in science and in expanding knowledge.

The wealthy universities of Oxford and Cambridge are gradually constructing laboratories for science. The merchant princes of Manchester have equipped their new Victoria University with similar laboratories. Edinburgh and Glasgow Universities have also done so, partly at the cost of Government and largely by private subscriptions. The poorer universities of Aberdeen and St. Andrews are still inefficiently provided with the modern appliances for teaching science.

London has one small Government college and two cbartered colleges, but is wholly destitute of a teaching university. It would excite great astonishment at the Treasury if we were to make the modest request that the great metropolis, with a population of $4,000,000$, should be put into as efficient academical position as the town of Strassburg, with 104,000 inhabitants, by receiving, as that town does, $43,000 l$. annually for academic instruction, and $700,000 l$. for university buildings. Still, the amazing anomaly that London has no teaching university must ere long cease.

It is a comforting fact that, in spite of the indifference of Parliament, the large towns of the kinglom are showing their sense of the need of higher education. Manchester has already its university. Nottingham, Birmingham, Leeds, and Bristol have colleges more or less complete. Liverfool converts a disused lunatic asylum into a college for sane people. Cardiff rents an infirmary for a collegiate building. Dundee, by private benefaction, rears a Baxter College with larger ambitions. All these are healthy signs that the public are determined to have advanced science teaching, but the resources of the institutions are altogether inadequate to the end in view. Even in the few cases where the laboratories are efficient for teaching purposes, they are inefficient as laboratories for research. Under these circumstances the Royal Commission on Science advocated special Government laboratories for research. Such laboratories, supported by public money, are as Jegitimate subjects for expenditure as galleries for pictures or sculpture ; but I think that they would not be successful, and would injure science if they failed. It would be safer in the meantime if the State assisted universities or well-established colleges to found laboratories of research under their own care. Even such a proposal shocks our Chancellor of the Exchequer, who tells us that this country is burdened with public debt, and has ironclads to build and arsenals to provide. Nevertheless our wealth is proportionally much greater than that of foreign States which are competing with so much vigour in the promotion of higher education. They deem such expenditure to be true economy, and do not allow their huge standing armies to be an apology for keeping their people backwards in the march of knowledge. France, which in the last ten years has been spending a million annually on university education, had a war indemnity to pay, and competes successfully with this country in ironclads. Either all foreign States are strangely deceived in their belief that the competition of the world has become a competition of intellect, or we are marvellously unobservant of the change which is passing over Europe in the higher education of the people. Preparations for war will not ensure to us the blessings and security of an enlightened peace. Protective expenditure may be wise, though productive expenditure is wiser.

"Were half the powers which fill the world with terror,

Were half the wealth bestowed on camps and courts,

Given to redeem the human mind from error-

There were no need of arsenals and forts."

Universities are not mere storehouses of knowledge ; they are 
also conservatories for its cultivation. In Mexico there is a species of ant which sets apart so ne of its individuals to act as boney-jars by monstrously extending their abdomens to store the precious fluid till it is wanted by the community. Professors in a university have a higher function, because they ought to make new honey as well as to store it. The widening of $\mathrm{th}$ : bounds of knowledge, literary or scientific, is the crowning glory of university life. Germany unites the functions of teaching and "esearch in the universities, while France keeps them in separate institutions. The former system is best adapted to our habits, but its condition for success is that our science chairs should be greatly increased so that teachers should not be wholly absorbed in the duties of instruction. Germany subdivides the sciennes nto various chairs, and gives to the professirs special laboratories. It also makes it a condition for the higher honours of a university that the candidates shall give proofs of their ability to make original researches. Under such a system, teaching and investigation are not incompatible. In the evidence before the Science Commission many opinions were piven that scientific men engaged in research should not be burclened with the duties of education, and there is much to be said in support of this view when a single professor for the whole range of a physical science is its only representative in a university. But I hope that such a system will not long continue, fo: if it do we must occupy a very inferior position as a nation in the intellectual competition of Europe. Research and cducation in limited branches of higher knowledge are not incompatible. It is true that Galileo complained of the burden imposed upon him by his numerous astronomical pupils, though few other philosophers have echoed this complaint. Newton, who produced order in worlds, and Dalton, who brought atoms under the reign of order and number, rejoiced in their pupils. Lalande spread astronomers as Liebig spread chemists, and Johannes Miiller biologists, all over the world. Laplace, La Grange, Dulong, Gay Lussac, Berthollet, and Dumas were professors as well as discoverers in France. In England our discoverers have generally been teachers. In fact, I recollect only three notable examples of men who werc not-Boyle, Cavendish, and Joulc. It was so in ancient as well as in modern times, for Plato and Aristotle taught and pbilosophised. If you do not make the investigator a schoolmaster, as Dalton was, and as practically our professors are at the present time, with the duty of teaching all branches of their sciences, the mere elementary truths as well as the highest generalisations being compressed into a course, it is well that they should be brought into contact with the world in which they live, so as to know its wants and aspirations. They could then quicken the pregnant minds around them, and extend to others their own power and love of research. Goethe had a fine perception of this when he wrotc-

\section{Wer in der Weltgeschichte lebt,}

Wer in die Zeiten schant, und strebt,

Nur der ist werth, zu sprechen und za dichten.

Our universities are still far from the attainment of a proper combination of their resources between teaching and research. Even Oxford and Cambridge, which have done so much in recen years in the equipment of laboratories and in adding to their scientific staff, are still far behind a second-class German university. The professional faculties of the English universities are growing, and will diffuse a greater taste for science among their students, though they may absorb the time of the limited professoriate so as to prevent it advancing the boundaries of knowledge. Professional faculties are absolutelv essential to the existence of universities in poor countries like Scotland and Ireland. This has been the case from the early days of the Bologna University up to the present time. Originally universities arose not by mere bulls of popes, but as a response to the strong desire of the professional classes to clignify their crafts by real knowledge. If their education hat been limited to mere technical schools lite the Medical School of Salerno which flourished in the eleventh century, len th but not breadih would have been given to education. So the universitics wisely joined culture to the professional scicnces. Poor countries like Scotland and Ireland must have their academic systems based on the professional faculties, although wealthy univer.ities like Oxford and Cambridge may continuc to have them as mere supplements to a more general education. A greater liberality of support on the part of the State in the establishment of chairs of science, for the sake of science and not merely for the teaching of the professions, would enable the poorer universities to take their part in the advancement of knowledge.
I have already alluded to the foundation of new colleges in different parts of the kingdom. Owens College has worthily developed into the Victoria University. Formerly she depended for deorees on the University of London. No longer will she bc like a moon reflecting cold and sickly rays from a distant luminary, for in future she will be a sun, a centre of intelligence, warming and illuminating the regions around her. The other colleges which have formed themselves in large manufacturing districts are remorkable expressions from them that science must be promoted. Including the colleges of a high class, such as University College and King's College in London, and the three Queen's Colleges in Ireland, the aggresate attendance of students in colleges withont university rank is between nine and ten thousand, while that of the universities is fifteen thousand. No doubt some of the provincial colleges require considerable improvement in their teaching methods; sometimes they unwisely aim at a full university curriculum when it would be better for them to act as faculties. Still, sthey are all growing in the spirit of self-help, and some of them are destined, like Owens College, to develop into universities. This is not a subject of alarm to Invers of erlucation, while it is one of hope and encouragement to the great centres of industry. There are too few autonomous universities in England in proportion to its population. While Se tland, with a population of $3^{\frac{8}{3}}$ millions, has four universities with 65 co students, England, with 26 millions of people, has only the same number of teaching universitics with 6000 students. Unles.; English colleges have such ambition, they may be turned into mere mills to grind out material for examinations and competitions. Higher colleges should always hold before their stuclents that knowledge, for its own sake, is the only object worthy of reverence. Beyond college life there is a land of research flowing with milk and honey for those who know how to cultivate it. Colleges should at least show a Pisgah view of this Land of Promise, which stretches far beyond the Jordan of examinations and competitions.

V. Science and Industry. - In the popular mind the value of science is measured by its applications to the useful purposes of life. It is no doubt true that science wears a beautiful aspect when she confers practical benefits upon man. But truer relations of science to industry are implied in Greck mythology. Vulcan, the god of industry, wooed science, in the form of Minerva, with a passionate love, but the chaste goddess never married, although she conferred upon mankind nearly as many arts as Prometheus, who, like other inventors, saw civilisation progressing by their use while he lay groaning in want on Mount Caucasus. The rapid development of industry in modern days depends on the applications of scientific knowledge, while its slower growth in former times was due to experiments being made by trial and error in order to gratify the needs of man. Then an experiment was less a questioning of Nature than an exercise on the mind of the experimentalist. For a true questioning of Nature only arises when intellectual conceptions of the causes of phenomena attach themselves to ascertained facts as well as to their natural environments. Much real science had at one time accumulated in Egypt, Greece, Rome, and Arabia, though it became obscurcd by the intellectual darkness which spread over Europe like a pall for many centuries. The mental results of Greek science, filtered through the Romans and Arabians, gradually fertilised the soil of Europe. Even in ages which are deemed to be dark and unprolific, substantial though slow progress was made. By the end of the fifteenth century the mathematics of the Alexandrian school had become the possession of Western Europe; Arabic numerals, algebra, trigonometry, decimal reckoning, and an improved calendar having been added to its stock of knowledge. The old dis. coveries of Democritus and Archimedes in physics, and of Hipparchus and $\mathrm{Pt}$,lemy in astronomy, were producing their natural developments, though with great slowness. Many manufactures, growing chiefly by experience, and occasionally lightened up by glimmerings of science throughout the pre vailing darkness, had arisen before the sixteenth century. A knowledge of the properties of bodies, though scarcely of their relations to each other, came through the labours of the alchemists, who had a mighty impulse to work; for by the philosopher's stone, often not larger than half a rape's sced, they hoped to attain the three sensuous conditions of human enjoyment-gold, health, and immortality. By the end of the fifteenth century many important manufactures were founded by empirical experiment, with only the uncertain guidance of science. Among these were the compass, printing, paper, gun- 
powder, guns, watches, forks, knitting-needles, horseshoes, bells, wood-cutting and copper-engraving, wire-drawing, steel, table glass, spectacles, microscopes, glass mirrors backed by amalgams of tin and lead, windmills, crushing and saw mills. These important manufactures arose from an increased knowledge of facts, around which scientific conceptions were slowly concreting. Aristotle defines this as science when he says, "Art begins when, from a great number of experiences, one general conception is formed which will embrace all similar cases." Such conceptions are formed only when culture developes the human mind and compels it to give a rational account of the world in which man lives, and of the objects in and around it, as well as of the phenomena which govern their action and evolution. Though the accumulation of facts is indispensable to the growth of science, a thousand facts are of less value to human progress than is a single one when it is scientifically comprehended, for it then becomes generalised in all similar cases. Isolated facts may be viewed as the dust of science. The dust which floats in the atmosphere is to the common observer mere incoherent matter in a wrong place, while to the man of science it is allimportant when the rays of heat and light act upon its floating particles. It is by them that clouds and rains are influenced; it is by their selective influence on the solar waves that the blue of the heavens and the beauteous colours of the sky glorify all Nature. So, also, ascertained though isolated facts, forming the dust of science, become the reflecting media of the light of knowledge, and cause all Nature to assume a new aspect. It is with the light of knowledge that we are enabled to question Nature through direct experiment. The hypothesis or theory which induces us to put the experimental question may be right or wrong; still, prudens questio dimidium scientice est-it is half way to knowledge when you know what you have to inquire. Davy described hypothesis as the mere scaffolding of science, useful to build up true knowledge, but capable of being put up or taken down at pleasure. Undoubtedly a theory is only temporary, and the reason is, as Bacon has said, that the man of science "loveth truth more than his theory." The changing theories which the world despises are the leaves of the tree of science drawing nutriment to the parent stems, and enabling it to put forth new branches and to produce fruit; and though the leaves fall and decay, the very products of decay nourish the roots of the tree and reappear in the new leaves or theories which succeed.

When the questioning of Nature by intelligent experiment has raised a system of science, then those men who desire to apply it to industrial inventions proceed by the same methods to make rapid progress in the arts. They also must have means to compel Nature to reveal her secrets. Eneas succeeded in his great enterprise by plucking a golden branch from the tree of science. Armed with this even dread Charon dared not refuse a passage across the Styx; and the gate of the Elysian fields was unbarred when he hung the branch on its portal. Then new aspects of Nature were revealed-

\section{Another sun and stars they know}

That shine like ours, but shine below."

It is by carrying such a golden branch from the tree of science that inventors are able to advance the arts. In illustration of how slowly at first and how rapidly afterwards science and its applications arise, I will take only two out of thousands of examples which lie ready to my hand. One of the most familiar instances is air, for that surely should have been soon understood if man's unaided senses are sufficient for knowledge. Air has been under the notice of mankind ever since the first man drew his first breath. It meets him at every turn; it fans him with gentle breezes, and it buffets him with storms. And yet it is certain that this familiar object-air-is very imperfectly understood up to the present time. We now know by recent researches that air can be liquefied by pressure and cold; but as a child still looks upon air as nothing, so did man in his early state. A ressel filled with air was deemed to be empty. But man, as soon as he began to speculate, felt the importance of air, and deemed it to be a soul of the world upon which the respiration of man and the god-like quality of fire depended. Yet a really intelligent conception of these two esscntial conditions to man's existence-respiration and combustion-was not formed till about a century ago (I775). No doubt long before that time there had been abundant speculations regarding air. Anaximenes, 548 years before Christ, and Diogenes of Apollonia, a century later, studied the properties of air so far as their senses would allow them ; so, in fact, did $A$ ristotle. Actual scientific experiments were made on air about the year n Ioo by a remarkable Saracen, Alhazen, who ascertained important truths which enabled Galileo, Torricelli, Otto de Guericke, and others at a later period to discover laws leading to important practical applications. Still there was no intelligent conception as to the composition of air until Priestley in 1774 repeated, with the light of science, an empirical observation which Eck de Sultach hac made 300 years before upon the union of mercury with an ingredient of air and the decomposition of this compound by heat. This experiment now proved that the active element in air is oxygen. From that date our knowledge, derived from an intelligent questioning of air by dircct experiments, has gone on by leaps and bounds. The air, which mainly consists of nitrogen and oxygen, is now known to contain carbonic acid, ammonia, nitric acid, ozone, besides hosts of living organisms which have a vast influence for good or evil in the economy of the world. These micro-orranisms, the latest contribution to our knowledge of air, perform great analytical functions in organic nature, and are the means of converting much of its potential cnergy into actual energy. Through their action on dead matter the mutual dependence of plants and animals is secured, so that the air becomes at oncc the grave of organic death and the cradile of organic life. No doubt the ancients suspected this without being able to prove the dependence. Euripides seems to have seen it deductively when he describes the results of decay :-

\section{"Then that which springs from earth, to earth returns, \\ And that which draws its being from the sky \\ Rises again up to the skyey beight."}

The consequences of the progressive discoveries have added largely to our knowledge of life, and have given a marvellous development to the industrial arts. Combustion and respiration govern a wide range of processes. The economical use of fuel, the growth of plants, the food of animals, the processes of hus. bandry, the maintenance of public health, the origin and cure of discase, the production of alcoholic drinks, the processes of making vinegar and saltpetre-all these and many other kinds of knowledge have been brought under the dominion of law. No doubt animals respired, fuel burned, plants grew, sugar fermented, before we knew how they depended upon air. But as the knowledge was empirical it could not be intelligently directed. Now all these processes are ranged in order under a wise cconomy of Nature, and can be directed to the utilities of lifc; for it is true, as Swedenborg says, that human "ends always ascend as Nature descends." There is scarcely a large industry in the world which has not received a mighty impuise by the better knowledge of air acquired within a hundred years. If I had time I could show still more strikingly the industrial advantages which have followed from Cavendish's discovery of the composition of water. I wish that I could have clone this, because it was $\Lambda$ ddision who foolishly said, and Paley who as unwisely approved the remark, "that mankind required to know no more about water than the temperature at which it froze and boiled, and the mode of making steam."

When we examine the order of progress in the arts, even before they are illumined by science, their irrprovements seem to be the resultants of three conditions :

(r) The substitution of natural forces for brute animal power, as when Hercules used the waters of the Alpheus to cleanse the Augean stables; or when a Kamchadal of Eastern Asia, who has been three years hollowing out a canoe, finds that he can do it in a few hours by fire.

(2) The economy of timc, as when a calendering machine produces the same gloss to miles of calico that an African savage gives to a few inches by rubbing it with the shell of a snail; or the economy of production, as when steel pens, sold when first introduced at one shilling apiece, are now sold at a penny per dozen; or when steel rails, lately costing $45 l$. per ton, can now be sold at $5 l$.

(3) Methods of utilising waste products, or of endowing them with propertics which render them of increased value to industry, as when waste scrap iron and the galls on the oak are converted into ink; or the badly-smelling waste of gasworks is transformed into fragrant essences, brilliant dyes, and fertilising manure ; or when the effete matter of animals or old bones is changed into lucifer-matches.

All three results are often combined when a single end is obtained-at all events, economy of time and production invariably follows when natural forces substitute brute animal 
force. In industrial progress the sweat of the brow is lessened by the conceptions of the brain. How exultant is the old Greek poet, Antipater, ${ }^{1}$ when women are relieved of the drudgery of turning the grindstones for the daily supply of corn. "Woman ! you who have hitherto had to grind corn, let your arms rest for the future. It is no longer for you that the birds announce by their songs the dawn of the morning. Ceres has ordered the water-nymphs to move the heavy millstones and perform your labour." Penelope had twelve slaves to grind corn for her small household. During the most prosperous time of Athens it was estimated that there were twenty slaves to each free citizen. Slaves are mere machines, and machines neither invent nor discover. The bondmen of the Jews, the helots of Sparta, the captive slaves of Rome, the serfs of Europe, and uneducated labourers of the present day who are the slaves of ignorance, have added nothing to human progress. But as natural forces substitute and become cheaper than slave labour, liberty follows advancing civilisation. Machines require educated superintendence. One shoe factory in Boston by its machine does the work of thirty thousand shoemakers in Paris who have still to go through the weary drudgery of mechanical labour. The steam power of the world, during the last twenty years, has risen from $I I_{\frac{1}{2}}$ million to 29 million horse-power, or 152 per cent.

Let me take a single example of how even a petty manufacture improved by the teachings of science affects the comforts and enlarges the resources of mankind. When I was a boy the only way of obtaining a light was by the tinder-box, with its quadruple materials, flint and steel, burnt rags or tinder, and a sulphur match. If everything went well, if the box could be found and the air was dry, a light could be obtained in two minutes; but very often the time occupied was much longer, and the process became a great trial to the serenity of temper. The consequence of this was that a fire or a burning lamp was kept alight through the day. Old Gerard, in his herbal, tells us how certain fungi were used to carry fire from one part of the country to the other. The tinder-box long held its position as a great discovery in the arts. The Pyxidicula iyniaria of the Romans appears to have been much the same implement, though a little ruder, than the flint and steel which Philip the Good put into the collar of the Golden Fleece in I429 as a representation of high knowledge in the progress of the arts. It continued to prevail till 1833, when phosphorus matches were introduced, though I have been amused to find that there are a few venerable ancients in London who still stick to the tinder box and for whom a few shops keep a small supply. Phosphorus was no new discovery, for it had been obtained by an Arabian called Bechel in the eighth century. However it was forgotten, and was rediscovered by Brandt, who made it out of very stinking materials in I669. Other discoveries had, however, to be made before it could be used for lucifer matches. The science of combustion was only developed on the discovery of oxygen a century later. Time had to elapse before chemical analysis showed the kind of bodies which could be added to phosphorus so as to make it ignite readily. So it was not till 1833 that matches became a partial success. Intolerably bad they then were, dangerously inflammable, horribly poisonous to the makers, and injurious to the lungs of the consumers. It required another discovery, by Schrötter in 1845 , to change poisonous waxy into innocuous red-brick phosphorus in order that these defects might be remedicd, and to give us the safety-match of the present day. Now what have these successive discoveries in science done for the nation, in this single manufacture, by an economy of time? If before 1833 we had made the same demands for light that we now do, when we daily consume eight matches per head of the population, the tinder-box could have supplied the demand under the most favourable conditions by an expenditure of one quarter of an hour. The lucifer-match supplies a light in fifteen seconds on each occasion, or in two minutes for the whole day. Putting these differences into a year the venerable ancient who still sticks to his tinder-box would require to spend ninely hours yearly in the production of light, while the user of lucifer-matches spends twelve hours; so that the latter has an economy of seventy-eight hours yearly, or about ten working days. Measured by cost of production at one shilling and sixpence daily, the economy of time represented in money to our population is twenty-six millions of pounds annually. This is a curious instance of the manner in which science leads to economy of time and wealth even in a small I "Analecta Veterum Graccorum," Epig. 39, vol. ii. p. 1 rg. manufacture. In larger industries the economy of time and labour produced by the application of scientific discoveries is beyond all measurement. Thus the discovery of latent heat by Black led to the inventions of Watt; while that of the mechanical equivalent of heat by Joule has been the basis of the progressive improvements in the steam-engine which enables power to be obtained by a consumption of fuel less than one-fourth the amount used twenty years ago. It may be that the engines of Watt and Stephenson will yield in their turn to more economical motors; still they have already expanded the wealth, resources, and even the territories of England more than all the battles fought by her soldiers or all the treaties negotiated by her diplomatists.

The coal which has hitherto been the chief source of power probably represents the product of five or six million years during which the sun shone upon the plants of the Carboniferous period, and stored up its energy in this convenient form. But we are using this conserved force wastefully and prodigally; for although horse power in steam-engines has so largely increased since 1864, two men only now produce what three men did at that date. It is only three hundred years since we became a manufacturing country. According to Prof. Dewar, in less than two hundred years more the coal of this country will be wholly exhausted, and in half that time will be difficult to procure. Our not very distant descendants will have to face the problem -What will be the condition of England without coal? The answer to that question depends upon the intellectual development of the nation at that time. The value of the intellectual factor of production is continually increasing; while the values of raw material and fuel are lessening factors. It may be that when the dreaded time of exhausted fuel has arrived, its importation from other coal-fields, such as those of New South Wales, will be so easy and cheap, that the increased technical education of our operatives may largely over-balance the disadvantages of increased cost in fuel. But this supposes that future Governments in England will have more enlightened views as to the value of science than past Governments have possessed.

Industrial applications are but the overflowings of science welling over from the fulness of its measure. Few would ask now, as was constantly done a few years ago, "What is the use of an abstract discovery in science?" Faraday once answered this question by another, "What is the use of a baby?" Yet around that baby centre all the hopes and sentiments of his parents, and even the interests of the State, which interferes in its upbringing so as to ensure it being a capable citizen. The processes of mind which produce a discuvery or an invention are rarely associated in the same person, for while the discoverer sceks to explain causes and the relations of phenomena, the inventor aims at producing new effects, or at least of obtaining them in a novel and efficient way. In this the inventor may sometimes succeed without much knowledge of science, though his labours are infinitcly more productive when he understands the causes of the effects which he desires to produce.

A nation in its industrial progress, when the competition of the world is keen, cannot stand still. 'Three conditions only are possible for it. It may go forward, retrograde, or perish. Its extinction as a great nation follows its neglect of higher education, for, as described in the proverb of Solomon, "They that hate instruction love death." In sociology, as in biology, there are three states. 'The first of balance, when things grow neither better nor worse ; the second that of elaboration or evolution, as we see it when animals adapt themselves to their environments; and third, that of degeneration, when they rapidly lose the ground they have made. For a nation, a state of balance is only possible in the early stage of its existence, but it is impossible when its environments are constantly changing.

The possession of the raw materials of industry and the existence of a surplus population are important factors for the growth of manufactures in the early history of a nation, but afterwards they are bound up with another factor-the application of intellect to their devclopment. England could not be called a manufacturing nation till the Elizabethan age. No doubt coal, iron, and wood were in abundance, though, in the reign of the Plantagenets, they produced little prosperity. Wool was sent to Flanders to be manufactured, for England then stood to Holland as Australia now does to Yorkshire. The political crimes of Spain, from the reign of Ferdinand and Isabella to that of Philip III., destroyed it as a great manufacturing nation, and indirectly led to England taking its position. Spain through the activity and science of the Arabian intellect, had 
acquired many important industries. The Moors and the Moriscoes, who had been in Spain for a period as long as from the Norman Conquest of this country to the present date, were banished, and with them departed the intellect of Spain. Then the invasion of the Low Countries by Philip II. drove the Flemish manufacturers to England, while the French persecution of the Hugtuenots added new manufacturing experience, and with them came the industries of cotton, wool, and silk. Cotton mixed with linen and wool became freely used, but it was only from 1738 to the end of the century that the inventions of Wyatt, Arkwright, Hargreaves, Cromyton, and Cartwright started the wonderful modern development. The raw cotton was imported froin India or America, but that fact as regards cost was a small factor in comparison with the intellect required to convert it into a utility. Science has in the last hundred years altered altogether the old conditions of industrial competition. She has taught the rigid metals to convey and record our thoughts even to the most distant lands, and, within less limits, to reproduce our speech. This marvellous application of electricity has diminished the cares and responsibilities of Governments, while it has at the same time altered the whole practice of commerce. To England steam and electricity have been of incalculable advantage. The ocean, which once made the country insular and isolated, is now the very life-blood of England, and of the greater England beyond the seas. As in the human body the blood bathes all its parts, and through its travelling corpuscles carries force to all its members, so in the body politic of England and its pelasgic extensions, steam has become the circulatory and electricity the nervous system. The colonies, being young countries, value their raw materials as their chief sources of wealth. When they become older they will discover that it is not in these, but in the culture of scientific intellect, that their future prosperity depends. Older nations recognise this as the law of progress more than we do; or, as Jules Simon tersely puts it- "That nation which most educates her people will become the greatest nation, if not to-day, certainly to-morrow.' Higher education is the condition of higher prosperity, and the nation which neglects to develope the intellectual factor of production must degenerate, for it cannot stand still. If we felt compelled to adopt the test of science given by Comte, that its value must be measured by fecundity, it might be prudent to claim industrial inventions as the immediate fruit of the tree of science, though only fruit which the prolific tree has shed. But the test is untrue in the sense indicated, or rather the fruit, according to the simile of Bacon, is like the golden apples which Aphrodite gave to the suitor of Atalanta, who lagged in his course by stooping to pick them up, and so lost the race. The true cultivators of the tree of science must seek their own reward by seeing it flourish, and let others devote their attention to the possible practical advantages which may result from their labours.

There is, however, one intimate connection between science and industry which $I$ hope will be more intimate as scientific education becomes more prevalent in our schools and universities. Abstract science depends on the support of men of leisure, either themselves possessing or having provided for them the means of living without entering into the pursuits of active industry. The pursuit of science requires a superfluity of wealth in a community beyond the needs of ordinary life. Such superfluity is also necessary for art, though a picture or a statue is a saleable commodity, while an abstract discovery in science has no immediate, or, as regards the discoverer, proximate commercial value. In Greece, when philosophical and scientific speculation was at its highest point, and when education was conducted in its own vernacular and not through dead languages, science, irdustry, and commerce were actively prosperous. Corinth carried on the manufactures of Birmingham and Sheffield, while Athens combined those of Leeds, Staffordshire, and London, for it had woollen manufactories, potteries, gold and silver work, as well as shipbuilding. Their philosophers were the sons of burghers, and sometimes carried on the trades of their fathers. Thales was a travelling oil merchant, who brought back science as well as oil from Egypt. Solon and his great descendant Plato, as well as Zeno, were men of commerce. Socrates was a stonemason; Thucydides a gold-miner ; Aristotle kept a druggist's shop until Alexander endowed him with the wealth of Asia. All but Socrates had a superfluity of wealth, and he was supported by that of others. Now, if our universities and schools created that love of science which a broad educacion would surely inspire, our men of riches and leisure who advance the boundaries of scientific knowledge could not be counted on the fingers as they now are, when we think of Boyle, Cavendish, Napier, Lyell, Murchison, and Darwin, but would be as numerous as our statesmen and orators. Statesmen, without a following of the people who share their views and back their work, would be feeble indeed. But while England has never lacked leaders in science, they have two few followers to risk a rapid march. We might create an army to support our generals in science, as Germany has done, and as France is now doing, if education in this country would only mould itself to the needs of a scientific age. It is with this feeling that Horace Mann wrote: "The action of the mind is like ithe action of fire : one billet of wood will hardly burn alone, though as dry as the sun and north-west wind can make it, and though placed in a current of air; ten such billets will burn well together, but a hundred will create a heat fifty times as intense as ten-will make a current of air to fan their own flame, and consume even greenness itself."

VI. Abstract Science the Condition for Progress. - The subject of my address has bten the relations of science to the public weal. That is a very old subject to select for the year 1885 . I began it by quoting the words of an illustrious prince, the consort of our Queen, who addressed us on the same subject from this platform twenty-six years ago. But he was not the first prince who saw how closely science is bound up with the welfare of States. Ali, the son-in-law of Mahomet, the fourth successor to the Caliphate, urged upon his followers that men of science and their disciples give security to human progress. Ali loved to say, "Eminence in science is the highest of honours," and "He dies not who gives life to learning." In addressing you upon texts such as these my purpose was to show how unwise it is for England to lag in the onward march of science when most other European Powers are using the resources of their States to promote higher education and to advance the boundaries of knowledge. English Governments alone fail to grasp the fact that the competition of the world has become a competition in intellect. Much of this indifference is due to our systems of education. I have ill fulfilled my purpose if, in claiming for science a larger share in public education, I have in any way depreciated literature, art, or philosophy, for every subject which adds to culture aids in human development. I only contend that in public education there should be a free play to the scientific faculty, so that the youths who possess it should learn the richness of their possession during the educative process. The same faculties which make a man great in any walk of life-strong love of truth, high imagination tempered by judgment, a vivid memory which can co-ordinate other facts with those under immediate consideration-all these are qualities which the poet, the philosopher, the man of literature, and the man of science equally require and should cultivate through all parts of their education as well as in their future careers. My contention is that science should not be practically shut out from the view of a youth while his education is in progress, for the public weal requires that a large number of scientific men should belong to the community. This is necessary because science has impressed its character upon the age in which we live, and, as science is not stationary, but progressive, men are required to advance its boundaries, acting as pioneers in the onward march of States. Human progress is so identified with scientific thought, both in its conception and realisation, that it seems as if they were alternative terms in the history of civilisation. In literature, and even in art, a standard of excellence has been attained which we are content to imitate because we have been unable to surpass. But there is no such standard in science. Formerly, when the dark cloud was being dissipated which had obscured the learning of Greece and Rome, the diffusion of literature or the discovery of lost authors had a marked influence on advancing civilisation. Now, a Chrysoloras might teach Greek in the Italian universities without hastening sensibly the onward march of Italy; a Poggio might discover copies of Lucretius and Quintilian without exercising a tithe of the influence on modern life that an invention by Stephenson or Wheatstone would produce. Neverthcless, the divorce of culture and science, which the present state of education in this country tends to produce, is deeply to be deplored, because a cultured intelligence adds greatly to the development of the scientific faculty. My argument is that no amount of learning without science suffices in the present state of the world to put us in a position which will enable England to keep ahead or even on a level with foreign nations as regards knowledge and its applications 
to the utilities of life. Take the example of any man of learning, and see how soon the direct consequences resulting from it disappear in the life of a nation, while the discoveries of a man of science remain productive amid all the shocks of empire. As I am in Aberdeen I remember that the learned Dutchman Erasmus was introduced to England by the encouragement which he received from Hector Boece, the Principal of King's College in this University. Yet even in the case of Erasmus - who taught Greek at Cambridge and did so much for the revival of classical literature as well as in the promotion of spiritual freedom-how little has civilisation to ascribe to him in comparison with the discoveries of two other Cambridge men, Newton and Cavendish. The discoveries of Newton will influence the destinies of mankind to the $\mathrm{nd}$ of the world. When he established the laws by which the motions of the great masses of matter in the universe are governed, he conferred an incalculable benefit upon the intellectual develop. ment of the human race. No great discovery flashes upon the world at once, and therefore Pope's lines on Newton are only a poetic fancy :-

Nature and Nature's laws lay hid in night,

God said, 'Let Newton be,' and all was light.'

No doubt the road upon which he travelled had been long in preparation by other men. The exact observations of Tycho Brabe, coupled with the discoveries of Copernicus, Kepler, and Galileo had already broken down the authority of Aristotle and weakened that of the Church. But though the conceptions of the universe were thus broadened, mankind had not yet rid themselves of the idea that the powers of the universe were still regulated by spirits or special providences. Even Kepler moved the planets by spirits, and it took some time to knock these celestial steersmen on the head. Descartes, who really did so $\mathrm{n}$ uch by his writings to force the conclusion that the planetary movements should be dealt with as an ordinary problem in mechanics, looked upon the universe as a machine, the wheels of which were kept in motion by the unceasing exercise of a divine power. Yet such theories were only an attempt to regulate the universe by celestial intelligences like our own, and by standards within our reach. It required the discovery of an allpervading law, universal throughout all space, to enlarge the thoughts of men, and one which, while it widened the conceptions of the universe, reduced the earth and solar system to true dimensions. It is by the investigation of the finite on all sides that we obtain a higher conception of the infinite-

$$
\text { "Willst du ins Unendliche schreiten, }
$$$$
\text { Geh nur im Endlichen nach allen Seiten." }
$$

Ecclesiastical authority had been already undermined by earnest inquirers, such as Wycliffe and Huss, before Luther shook the pillars of the Vatican. They were removers of abuses, but were confined within the circles of their own beliefs. Newton's discovery cast men's minds into an entirely new mould, and levelled many barriers to human progress. This intellectual result was vastly more important than the practical advantages of the discovery. It is true that navigation and commerce mightily benefited by our better knowledge of the motions of the heavenly bodies. Still these benefits to humanity are incomparably less in the history of progress than the expansion of the human intellect which followed the withdrawal of the cramps that confined it. Truth was now able to discard authority, and marched forward without hindrance. Before this point was reached Bruno had been burned, Galileo had abjured, and both Copernicus and Descartes had kept back their writings for fear of offending the Church.

The recent acceptance of evolution in biology has had a like effect in producing a far profounder intellectual change in human thought than any mere impulse of industrial development. Alrcady its application to sociology and eclucation is recognised, but that is of less import to human progress than the broadening of our views of Nature.

Abstract discovery in science is then the true foundation upon which the superstructure of modern civilisation is built; and the man who would take part in it should study science, and, if he can, advance it for its own sake and not for its applications. Ignorance may walk in the path lighted by advancing knowledge, but she is unable to follow when science passes her, for, like the foolish virgin, she has no oil in her lamp.

An established truth in science is like the constitution of an atom in matter-something so fixed in the order of things that it has become independent of further dangers in the struggle for existence. The sum of such truths forms the intellectual treasure which descends to each generation in hereditary succession. Though the discoverer of a new truth is a benefactor to humanity, he can give little to futurity in comparison with the wealth of knowledge which he inherited from the past. We, in our generation, should appreciate and use our great possessions--

$$
\begin{aligned}
& \text { "For me your tributary stores combine, } \\
& \text { Creation's heir ; the world, the world is mine." }
\end{aligned}
$$

\section{SECTION A.}

MATHEMATICAL AND PHYSICAL SCIENCE.

Opening Address by Prof. G. Chrystal, M.A., F.R.S.E., President of the Section.

WHEN a man finds himself unexpectedly in some unusual situation his first impulse is to look around and see how others have done in like circumstances. I have accordingly run through the addresses of my predecessors in the honourable office of president of Section A, which is fated this year to be filled somewhat unworthily. This examination, has, I am bound to say, comforted me not a little. I have found precedents for all kinds of addresses, long and short, even apparently for none at all. The variety of subjects is also suggestive of great latitude. I have found reviews of the progress of mathematical and physical science, discussions of special scientific subjects, dissertations on the promotion of scientific research, and on the teaching and diffusion of science, all chosen in their turn for the subjects of this opening acldress.

Following some of the most eminent of my forerunners, I propose to be brief; following the last of them, Prof. Henrici, I shall take for my subject, so far as $\mathrm{J}$ have one, the Diffusion of Scientific Knowledge. Apart from the fact that Prof. Henrici's address greatly interested me, and that I find many of his conclusions in agreement with the results of my own experience, and that, therefore, I wish to second him with all my power, I have other reasons for this choice, For more than half the year I am employed with absolute continuity in teaching mathematics, and it has happened for the last eight years or so that the other half has been mainly occupied in a variety of ways with scienceteaching generally. This is the thing concerning which $\mathrm{I}$ have had most experience, and I hold it to be the most respectful course towards my audience to speak to them on the subject that I know best.

Ever since I began to study science I have been deeply interested in the question of how it could best be taught. I believe my meditations in that direction were awakened by some unsuccessful boyish efforts to apply to the satisfaction of a ploughman, who was my friend and confidant, certain principles of natural philosophy to explain the action of his plough. Wisely and unwisely $I$ have always been ardent about the improvement of scientific teaching. I was so long before I dreamt that I should one day be called upon to put my ideas through the cold ordeal of practice. It would not be lecoming that I should speak at any time, more particularly to-dlay, regarding the success of my own efforts, or even regarding my alternate fits of hopefulness and despair. It is enough to say that, in such a cause,

$$
\text { " "Tis better to have loved and lost, }
$$

The British Association, by its title, exists for the advancement of science. Now, I hold that one of the essential conditions for that advancement is the existence of a scientific public-a public, like the Athenians of old, eager to hear and tell of some new truth; eager to discuss and eager to criticise ; ready to appreciate what is novel ; to receive it if sound, to reject it if unsound. It is to such a public that the British Association appeals, and certainly in the past it has not found its public wanting in generosity. What I should wish to sec is less of mere friendly onlooking and more participation in the dance.

I am not speaking now merely of a professional public, such as is so prominent in Germany for instance, made up of teachers and others professionally concerned with science. I refer mainly to that amateur but truly expert public which has always been so honourable a feature of English science, as examples of which I may mention Boyle and Cavendish in former days, and Joule and Spottiswoode in our own. It is quite true that much of that scientific public came in clays of yore from the leisured class, whose ratio to the rest of the nation will not improbably decrease in the course of our social development. I think, however, that the loss we may thus sustain will be more than compensated by 
the continual increase of those who have received higher educa tion of some kind or other, and whose daily occupations give them an interest, direct or indirect, in one or more branches of science.

It may not be amiss to insist for a littlc on the advantages to science of a great body of men unolicially engaged in scientific research, in writing regarding science, or even in merely turning scientific matler over in their minds. It will not have escaped the notice of those among you who have studied the history of science, that few scientific ideas spring up suddenly without previous trace or history. It is perfectly true that in many cases some mind of unwonted breadth and firmness is required to formulate the new doctrine, and carry it to manifold fruition but a close examination always shows that the sprite was in the air before the Prospero came to catch him. It is very striking to notice, in the history of Algebra for instance, Jong periods in which great improvements were effected in the science, which cannot be traced to any individual, but seem to have been due merely to the working of the minds of scientific men generally upon the matter, one giving it this little turn, another that, in the main always for the better. Like every other thing that has the virtue of truth in it, science grows as it goes, not like the idle gossiping tale by the casual accretion of hetcrogeneous matter, but by the chemical combination of pure element with purc element in reasonable proportion.

I know of no greater advantage for science than the existence of an army of independent workers sufficiently enlightened for self-criticism, who shall test the results and theories of their day. Great and indispensable as arc the uses of professional schools of scientific workmen, they are open to one great and insidious danger. The temptation there to swear by the word of the master is often irresistible. Not to speak of its being often the readiest avenue to fams and profit, it is the perfectly natural consequencc of the contact of smaller mind with greater.

There are few things where the want of an enlightened scientific public strikes an expert more than the matter of scientific text-books. If the British public were educated as it ought to be, publishers would not be able to palm off upon them in this guise the ill-paid work of fifth-rate workmea so often as they do; nor would the scientific articles and reviews in popular journals and magazines so often be written by men so palpably ignorant of their subject.

We all have a great respect for the integrity of our British legislators, whatever doubts may haunt us occasionally as to their capacity in practical affairs. The ignorance of many of them regarding some of the most elementary facts that bear on everyday life is very surprising. Scientifically speaking, uncducated themselves, they seem to think that they will catch the echo of a fact or the solution of an arithmetical problem by putting their ears to the sounding-shell of uneducated public opinion. When I observe the process which many such people employ for arriving at what they consider truth, I often think of a story I once heard of an eccentric Gcrman student of chemistry. This genteman was idle, but, like all his nation, systematic. When he had a precipitate to wcigh, instead of resorting to his balance, he would go the round of the laboratory, hold up the test-tube before each of his fellow-students in turn, and ask him to guess the weight. He then set down all the replies, took the average, and entered the result in his analysis.

I will not take up your time in insisting upon the necessity of the diffusion of science among that large portion of the public who are, or ought to be, appliers of scientific knowledge to practical life. That part of my theme is so obvious, and has been of late so much dwelt upon, that I may pass it by, and draw your attention to another place in which the shoe pinches. All of you who have taken any practical interest in the organisation of our educational institutions must be aware of the great difficulty in securing the services of non-professional men of sufficient scientific knowledge to act on School Boards, and undertake the direction of our higher schosls. It is no secret among those who carefully watch the course of the times in these matters that our present organisation is utterly insufficient ; that it has not solved, and shows every day less likelihood of solving, the problems of higher education. This arises, to a great extent, from the fact that a scientifically educated public of the extent presupposed by the organisation really does not at present exist.

If the existence of a great scientific public be as important as I think I have shown it to be, it must be worth while to devote a few moments to the consideration of the means we adopt to produce it both in the rising and in the risen generation.
It would naturally be expected that we should look carefully to the scientific education of our youth, to see that the best men and the best means that could be had were devoted to it; that we should endeavour to make for them a broad straight road to the newest and best of our scientific ideas; that we should exercisc them when young on the best work of the greatest masters ; familiarise them early with the great men and the great feats of scicnce, both of the past and of the present; that we should avoid retarding their progress by making the details and illustrations or particular rules and methods end in themselves. Granting that it is impossible to bring every learner within reach of the fullest scientific knowledge of his time, it would surely be reasonable to take care that the little way we lead him should not be along some devious by-path, but towards some eminence from which he might at least see the promised land. The end of all scientific training of the great public I take to be, to cnable each member of it to look reason and nature in the face, and judge for himself what, considering the circumstances of his day, may be known, and not be deceived regarding what must to him remain unknown. If this be so, surely the ideal of scientific education which I have sketched is the right one : yet it is most certainly not the ideal of our present system of instruction. To attain conviction on that head it is sufficient to examine the text-books and examination papers of the day.

Let us confine ourselves for the present to the most elementary of all the exact sciences, viz., geometry and algebra. These two, although among the oldest, are, as Professor Cayley very justly reminded the Association last year, perhaps the most progressive and promising of all the sciences. Great names of antiquity are associated with them, and in modern times an army of men of genius have aided their advance. Moreover, it cannot be said that this advance concerns the higher parts of these sciences alone. On the contrary, the discoveries of Gauss, Lobatschewsky, and Riemann, and of Poncelet, Möbius, Steiner, Chasles, and Von Standt, in geometry, and the labours of Dc Morgan, I Jamilton, and Grassman, not to mention many others, in algelra, have thrown a flood of light on the elements of both these subjects. What traces of all this do we find in our school books? To be sure antiquity is stamped upon our geometry, for we use the tcxt-book of Euclid, which is some two thousand years old ; but where can we point to the influence of modern progress in our geometrical teaching? For our teaching of algebra, I am afraid, we can claim neither the sanction of antiquity nor the light of modern times. Whether we look at the elementary, or at what is called the higher teaching of this subject, the result is unsatisfactory. With respect to the former, my experience justifies the criticism of Professor Henrici ; and I have no doubt that the remedy he suggests would be effectual. In the higher teaching, which interests me most, I have to complain of the utter neglect of the all-important notion of algebraic form. I found, when I first trieu to teach University students co-ordinate geometry, that I had to go back and teach them algebra over again. The fundamental idea of an integral function of a certain degree, having a certain form and so many coefficients, was to them as much an unknown quantity as the proverbial $x$. I found that their notion of higher algebra was the solution of harder and harder equations. The curious thing is that many examination candidates, who show great facility in reducing exceptional equations to quadratics, appear not to have the remotest idea beforehand of the number of solutions to be expected; and that they will very often produce for you by some fallacious mechanical process a solution which is none at all. In short, the logic of the subject, which, both educationally and scientifically spcaking, is the most important part of it, is wholly neglected. The whole training consists in example grinding. What should have bcen merely the help to attain the end has become the end itsclf. The result is that algebra, as we teach it, is neither an art nor a science, but an ill-chigested farrago of rules, whose object is the solution of examination problems.

The history of this matter of problems, as they are called, illustrates in a singularly instructive way the weak point of our English system of education. They originated, I fancy, in the Cambriclge Mathematical Tripos Examination, as a reaction against the abuses of cramming bookwork, and they have spread into almost every branch of science teaching-witness testtubing in chemistry. At first they may have been a good thing at all events the tradition at Cambridge was strong in my day, that he that could work the most problems in three or two and a half hours was the ablest man, and, be he ever so ignorant of bis subject in its width and breadth, could afford to despise those 
less gifted with this particular kind of superficial sharpness. But, in the end, came all to the same: we were prepared for problemworking in exactly the same way as for bookwork. We were directed to work through old problem papers, and study the style and peculiarities of the day and of the examiner. The day and the examiner had, in truth, much to do with it, and fashion reigned in problems as in everything else. The only difference I could ever see between problems and bookwork was the greater predominance of the inspiriting element of luck in the former. This advantage was more than compensated for by the peculiarly disjointed and, from a truly scientific point of view, worthless nature of the training which was employed to cultivate this species of mental athletics. The result, so far as problems worked in examinations go, is, after all, very miserable, as the reiterated complaints of examiners show; the effect on the examinee is a well-known enervation of mind, an almost incurable superficiality, which might be called Problematic Paralysis -a disease which unfits a man to follow an argument extending beyond the length of a printed octavo page. Another lamentable feature of the matter is that an enormous amount of valuable time is yearly wasted in this country in the production of these scientific trifles. Against the occasional working and propounding of problems as an aid to the comprehension of a subject, and to the starting of a new idea, no one objects, and it has always been noted as a praiseworthy feature of English methods, but the abuse to which it has run is most pernicious.

All men practically engaged in teaching who have learned enough, in spite of the defects of their own early training, to enable them to take a broad view of the matter, are agreed as to the canker which turns everything that is good in our educational practice to evil. It is the absurd prominence of written competitive examinations that works all this mischief. The end of all education nowadays is to fit the pupil to be examined; the end of every examination not to be an educational instrument, but to be an examination which a creditable number of men, however badly taught, shall pass. We reap, but we omit to sow. Consequently our examinations, to be what is called fair - that is, beyond criticism in the newspapers-must contain nothing that is not to be found in the most miserable text-book that any one can cite hearing on the subject. One of my students, for example, who was plucked in his M.A. examination, and justly so if ever man was, by the unanimous verdict of three examiners, wrote me an indignant letter because he believed, or was assured, that the paper set by the examiners could not have been answered out of Todhunter's Elementary Algebra. I have nothing to say, of course, against that or any other text-book, but who put it into the poor young man's head that the burden lay with me to prove that the examination in question ought to contain nothing but what is to be found in Todhunter's Elementary Algebra? The course of this kind of reasoning is plain enough, and is often developed in the newspapers with that charming simplicity which is peculiar to honest people who are, at the same time, very ignorant and very unthinking. First, it follows that lectures should contain nothing but what is to be found in every text-book; secondly, lectures are therefore useless, since it is all in the text-book ; thirdly, the examination should allude to nothing that is not in the text-books, because that would be unfair ; fourthly, which is the coach or crammer's deduction, there should be nothing in the text-book that is not likely to be set in the examination. The problem for the writer of a text-book has come now, in fact, to be this-to write a book so neatly trimmed and compacted that no coach, on looking through it, can mark a single passage which the candidate for a minimum pass can safely omit. Some of these textbooks I have seen, where the scientific matter has been, like the lady's waist in the nursery song, compressed "so gent and sma'," that the thickness of it barely, if at all, surpasses what is devoted to the publisher's advertisements. We shall return, I verily believe, to the Compendium of Martianus Capella. The result of all this is that science, in the hands of specialists, soars higher and higher into the light of day, while educators and the educated are left more and more to wander in primeval darkness.

When our system sets such mean ends before the teacher, and encourages such unworthy conceptions of education, is it to be wondered at that the cry arises that pupils degenerate beneath even the contemptible standards of our examinations? These can hardly be made low enough to suit the popular taste. It is no merit of the system we pursue, but due simply to the better educated among our teachers-men, many of them, who work for little reward and less praise-that we have not come to a worse pass already. Somie even of the much-abused crammers have conceptions of a teacher's duty far higher than the system-mongers of the day, whom it. is their special business to outwit ; and it is but fair to allow to such of these also as deserve it part of the credit of stemming the torrent of degeneration. We place our masters in positions such that their very bread depends upon their doing what many of them know and will acknowledge to be wrong: Their excuse is, "We do so and so because of the examination."

The cure for all this evil is simply to give effect to a higher ideal of education in general, and of scientific education in particular. Science cannot live among the people, and scientific education cannot be more than a wordy rehearsal of dead textbooks, unless we have living contact with the working minds of living men. It takes the hand of God to make a great mind, but contact with a great mind will make a little mind greater. The most valuable instruction in any art or science is to sit at the feet of a master, and the next best to have contact with another who has himself been so instructed. No agency that I have ever seen at work can compare for efficiency with an intelligent teacher, who has thoroughly made his subject his own. It is by providing such, and not by sowing the dragon's teeth of examinations, that we can hope to raise up an intelligent generation of scientifically educated men, who sball help our race to keep its place in the struggle of nations. In the future we must look more to men and to ideas, and trust less to mere systems. Systems have had their trial. In particular, systems of examination have been tested and found wanting in nearly every civilised country on the face of the earth. Backward as we are here, we are stirring. The University of London, after rendering a great service to the country by forcing the older universities to give up the absurd practice of restricting their advantages to persons professing a particular shade of religious belief, has for many years pursued its career as a mere examining body. It has done so with rare advantages in the way of Government aid, efficient organisation, and an unsurpassed staff of examiners. Yet it has been a failure as an instrument for promoting the higher education-foredoomed to be so, because, as I have said, you must sow before you can reap. At the present time, with great wisdom, the managers of that institution have set about the task of really fitting it out for the great end that it professes to pursue. If they succeed in so doing, they will confer upon the higher education one of the greatest benefits it has yet received. They have an opportunity before them of dethroning the iron tyrant Examination which is truly enviable. This movement is only one of the signs of the times. Among the younger generation I find few or none that have any belief in the "learn when you can and we will examine you " theory ; and small wonder, for they have tasted the bitterness of its fruit. Laissez faire as a method in the higher education no longer holds its place, except in the minds of inexperienced elderly people, who cling, not unnaturally, to the views and fashions which were young when they were so.

All the same, the task of reformation is not an easy one. Examinations have a strong hold upon us, for various reasons, some good, some bad, but all powerful. In the first place, they came in as an outlet from the system of patronage, which, with many obvious advantages, some of which are now sorely missed, had become unsuited to our social conditions. There is a certain advantage in examinations from the organiser's point of view, which any one who, like myself, has to deal with large quantities of pretty raw material, will readily understand. Again, there is an orderly bustle about the system that pleases the business-loving eye of the Briton. Yearly the printed sheets go forth in every corner of the land. The candidates meet and, in the solemn silence of the examination hall, the inspector, the local magnate, or the professor, sits, while for two or three busy hours the pens go scratching over the paper. A feeling of thankfulness comes over the important actor in this well-ordered scene, that the younger generation have such advantages that their fathers never knew. It is only when the answers are dissected in the examiner's study that the rottenness is revealed underlying the fair outward skin. But then the examiner must go by his standards; he must consider what is done elsewhere, and what is to be reasonably expected. Accordingly he takes his report and quickly writes so many per cent. passed. Then the chorus of reporting examiners lift up their voices in wonderful concordance ; and all, perhaps even the examiners, are comforted. There is something attractive about the whole thing that I can only compare to the pleasure with which one listens to the hum of a busy factory or to the 
roaring of the forge and ringing of the anvil. But what avails the hum of the factory if the product be shoddy, and what the roar of the forge and the ring of the anvil if the metal we work be base?

In conclusion, let us consider for a moment what might be done for the risen generation, who are too old to go formally to school, and yet not too old to learn. In their education such bodies as the British Association might be very helpful. Indced, in the past, the British Association has been very helpful in many ways. It can point to an admirable series of reports on the progress of science, for which every one who, like myself, has used them, is very grateful. It is much to be desired that these reports should be continued, and extended to many branches of science which they have not yet covered.

The Association has at present, I believe, a committee of inquiry into science-teaching generally. This is typical of a kind of activity which the Association might very profitably extend. This Association, with its long list of members bristling with the names of experts in every science, not drawn from any clique or particular centre, but indiscriminately from the whole land, might take upon itself to look into the question of scientific text-books and treatises. Even if it did not set up a censorship of the scientific press, which might be an experiment of doubtful wisdom, although some kind of interference seems really wanted now and then, it might set itself to the highly useful work of filling the gaps in our scientific literature. There is nothing from which the English student suffers so much as the want of good scientific manuals. The fact is that the expense of getting up such books in this country is so great, and the demand for them, though steady, yet so limited, that it will not pay publishers to issue them, let alone remunerate authors to write them. In my student-days the scarcity was even greater than it is now, and in fact then no one could hope to get even a reasonable acquaintance with the higher branches of exact science unless he had some familiarity with French or German at the very least-a familiarity which was rare among my fellow-students either in England or in Scotland, Might not the British Association now and then request some one fitted for the task to write a treatise on such and such a subject, and offer him reasonable remuneration for the time, labour, and skill required?

Another field in which the Association might profitably extend its labours appears to me to be the furnishing of reports, from time to time, on the teaching of science in other countries, and the drawing up of programmes of instruction for the guidance of schoolmasters and of those who are reading for their own instruction. There is no need to impose these programmes on any one. I would leave as much freedom to the teacher as I would to the private student. The programme drawn up by the Society for the Improvement of Geometrical Teaching, for example, has been very useful to me as a teacher, although I do not follow it or any other system exclusively. The great thing is not to fal asleep over any programme or system. For the matter of that, Euclid would do very well in the earlier stages of school instruction at least, provided he were modernised, and judiciously discarded at that part of the student's career where a lighter vehicle and more rapid progress becomes neccssary. In such programmes as I contemplate the bearing of recent discovery on the elements of the various sciences could be pointed out, and the general public kept in this way from that gross ignorance into which they are at present allowed to fall.

The British Association has of late, I believe, given its atten tion to the encouragement of local scientific activity. There can be no doubt that much could be done in this way that is not done at present. The concentration of scientific activity in metropolitan centres is beginning to have a depressing effect in Great Britain. This is seen in the singularly unequal way in which Government aid is distributed over the country. Large sums are spent-sometimes we outsiders think not to the best purpose -through certain channels, simply because these channels happen to have a convenient opening in some Government office in London, or in some place in that important city which has easy access to the ruling powers; while applications on behalf of other objects not less worthy are met with a refusal which is sometimes barely courteous. The result is that local effort languishes, and men of energy, finding that nothing can be done apart from certain centres, naturally gravitate thither, leaving provincial desolation to become more desolate.

I think our great scientific societies-the Roval Societies of London and Edinburgh and the Royal Irish Academy-might do more than they do at present to prevent this languishing of local science, which is so prejudicial to the growth of a scientific public. Besides their all-important publishing function, these bodies have for a considerable time back been constituted into a species of examining and degree-conferring bodies for grown-up men. That is to say, their membership has been conferred upon a principle of exclusion. Instead of any one being admitted who is willing to do his best, by paying his subscription or otherwise, to advance science, every one is excluded who does not come up to the standard of a certain examining body. So far is this carried in the case of the Royal Society of London, that there is an actual competitive examination, on the result of which a certain number of successful candidates are annually chosen. Now, against this proceeding by itself I have nothing to say, except that it appears to belong to the pupillary age both of men and nations. It is not the honouring of the select few that I think evil, but the exclusion of the unhonoured many. The original intention in founding these societies was to promote the advancement of science. How that is done by excluding any one, be it the least gifted among us, who is honestly willing to contribute his mite towards the great end, fairly passes my comprehension. If it is thought necessary, for the proper cultivation of the scientific spirit among us, that the degree-conferring function should be continued, let there by all means be an inner court of the temple, a place for titular immortals; but let there be also a court of the Gentiles, where those whose fate or whose choice it is to serve science unadorned may find a modest recep. tion. I believe that the adoption of this suggestion would enormously extend the usefulness of our great scientific societies, and give to their voice a weight which it never had before. At all events, if the trammels of tradition, or some better reason with which I am unacquainted, should prevent them from broadening their basis in the way I indicate, nothing prevents the British Association, with its more liberal constitution, from considering what may be done for the scientific plebeian.

There is one other function of the British Association in connection with which I wish to venture another suggestion. During the annual meeting, scientific men have an opportunity of making each other's acquaintance. Great men exchange ideas with great men; and, most important of all, young and little men have a chance, rarely otherwise afforded, of taking a nearer view of the great. What I would suggest for consideration is, whether it might not be possible to form an organisation which would in a certain sense carry this advantage through the whole year. I have already alluded more than once to the difficulties that the scientific public-and here I include professional men generally, in fact all but the leaders of science-have in keeping pace with recent advances. Would it not be possible to have an arrangement enabling at least every large centre of the higher education to have periodically the benefit of communion with and instruction from the high priests of the various branches of science? How glad we, the teachers of science in Edinburgh for example, would be to have a course of lectures once every three or four ycars from Professors Cayley, Sylvester, Stokes, Adams, Iord Rayleigh. In this way effect would be given to the principle which cannot be too much insisted upon, that the power of the spoken word far exceeds that of the written letter. Not only should we learn from the mouths of the prophets themselves the highest truths of science, but the present generation would thus come to know face to face, as living men, those whose work will be the glory of their time and a light for future ages. From the want of a proper circulating medium, the influence of great scientific men very often does not develop until they and the secrets of their insight have gone from among us. The object of what I propose is to make these men more of a living power in their own lifetime.

\section{SECTION B}

CHEMICAL SCIENCE

Opening Address by Prof. Henry E. Armstrong, Ph.D., F.R.S., Sec. C.S., President of the Sectton

In the Chemical Section of the British Association for the Advancement of Science the advancement of chemistry throughout the British Empire must be a subject of commanding interest. Signs of such advancement are not wanting:- the rapid establishment of science colleges in one after another of our large towns; the establishment of the Society of Chemical Industry, which now, only in the fifth year of its existence, 
numbers over 2,000 members; the granting of a Royal charter to the Institute of Chemistry ; the changes introduced at the London University in the regulations for the D.Sc. degree; the report of the Royal Commission on Technical Education, in which the value to chemical manufacturers of advanced chemical know. ledge is so fully recognised ; the important conference on education held at the Health Exhibition last year; the recent agitation to found a teaching university in London with adequate provision for research-surely all these are signs that the value of higher education must and will, ere long, be generally recognised.

The neglect of chemical research in our British schools has often been forcibly commented upon - of late, especially, by an eminent past-President of this section, Dr. Perkin, whose opinion is of peculiar value, as he is not only world renowned as a chemist, but also as a manufacturer: indeed, as the founder of two distinct important chemical industries. There can be no doubt of the fact and of the dire consequences to our country of such neglect: how is it, then, that such pronounced complaints have been so coldly received; that hitherto they have produced comparatively so little effect; and that such slight encouragement is being given to those who, notwithstanding the many difficulties in their way, have steadfastly devoted themselves to research work? I question whether the value of such work has yet been brought home to teachers generally, let alone the public : the "cui bono?" cry is almost invariably met by pointing to some discovery of great pecuniary value as the outcome of research. This argument educationalists very properly refuse to recognise. Too little has been said as to the cause of the neglect so bitterly and properly complained of. Hence it is that I propose again to take up what many may regard as a somewhat threadbare theme.

Every one will agree with Prof. Sir Henry Roscoe, who in his address last year to this Section said " that those who are to become either scientific or industrial chemists should receive as sound and extensive a foundation in the theory and practice of chemical science as their time and abilities will allow, rather than they should be forced prematurely "" into the preparation of a new series of homologous compounds, or the investigation of some special reaction, or of some possible new colouring matter, though such work might doubtless lead to publication." We must also cordially agree with him that the aim should be, as he tells us his has been, "to prepare a young man by a careful and fairly complete general training to fill with intelligence and success a post either as teacher or industrial chemist, rather than to turn out mere specialists, who, placed under other conditions than those to which they have been accustomed, are unable to get out of the narrow groove in which they have been trained." If it were necessary to show that Sir Henry Roscoe is a believer in research in its proper place, ample proof would be afforded by his statement, " that, far from underrating the educational advantages of working at original subjects, he considers this sort of training of the highest and best kind, but only useful when founded upon a sound and general basis."

But I venture to think that something has to be added in order to completely define the position of those who deplore the slight amount of original work which is being done in British laboratories. We maintain that no one can really " fill with intelligence and success a post either as teacher or industrial chemist" who has not been trained in the methods of research; and that, owing to the neglect of research, the majority of students are of necessity trained in a narrow groove. The true teacher and the industrial chemist are daily called upon to exercise precisely those faculties which are developed in the course of original investigation, and which it is barely possible-many would say, perhaps with justice, it is impossible-to sufficiently cultivate in any other manner. In a works the chemist is scarcely required as long as all goes well. The quality of the materials used or produced can be controlled by purely routine processes of analysis by the works analyst, or by well-trained laboratory boys. But things never do go well for any long period of time : difficulties are always arising; obscure points have to be investigated ; and, if the manufacturer understand his business, improvements have to be effected-which cannot be done unless the conditions under which he is working be understood, as well as the character of the changes which are taking place. Investigation is therefore necessary at every step. No amount of instruction, such as is ordinarily given, in the mere theory and practice of chemical science will confer the habits of mind, the acuteness of vision and resourcefulness required of an efficient chemist in a works, any more than the mere placing of the best tools in a workman's hands will make him a skilful operator.

Such being our position, we maintain that it is essential to make research an integral portion of the student's course in every college which pretends to educate chemists. It will not suffice occasionally to set a promising student to investigate, but a number of students, as well as the staff, must always be engaged in original work: in fact, an atmosphere of research must pervade the college. It cannot be too clearly recognised that it is this which characterises and distinguishes the German schools at the present time. The student does not learn so much from the one special piece of work with which he is occupied, but a number of his fellow-students being also similarly engaged, the spirit of inquiry is rife throughout the laboratory: original literature is freely consulted, and they thus become acquainted with the methods of the old masters; vigorous discussions take place, not only in the laboratory, but also at that most useful institution, the "Kneipe"; the appearance of each new number of the scientific periodicals is keenly welcomed; -in fact, a proper spirit of inquisitiveness is awakened and maintained, until it gradually becomes a habit. Probably there is less actual routine teaching done by the staff in the German schools than in our own. I am proud to own my indebtedness to one of them, and I can without hesitation say that I never truly realised what constituted the science of chemistry until I came under its influence.

But to realise the state which I have pictured-to create an atmosphere of research in our science colleges in order that it may be possible for our students to obtain complete training in chem. istry, several things are required. In the first place, it will be necessary that the students come to them better prepared than they are at present : as a rule they are so ill-prepared that it is very difficult, if not impossible, in the time at disposal to give such preliminary instruction as is indispensable before higher work can be attempted. Their mathematical knowledge is so ill-digested that it is more often than not necessary to begin by teaching simple proportion, and they look aghast at a logarithm table. They cannot draw ; so far have we advanced in our civilisation that the subject is more often than not an "extra" in our schools. They understand a little French; but German, which may almost be called the language of modern science, is indeed an unknown tongue to them. I do not complain of their want of knowledge of science subjects, but of the unscientific manner in which they have been trained at school, and especially of the manner in which their intellectual faculties have become deadened from want of exercise, instead of developed and sharpened. Too many have never acquired the habit of working steadily and seriously ; they have not learnt to appreciate the holiness of work, ${ }^{1}$ so that they render the office of teacher akin to that of slave-driver instead of to that of friend. What is perhaps worst is their marked inability, often amounting to downright refusal, either to take proper notice of what happens in an experiment or to draw any logical conclusion from an observation. Man is said to be a reasoning being, but my experience as an examiner and teacher would lead me to believe that this fact is altogether lost sight of by the average schoolmaster, who appears to confine himself almost exclusively to the teaching of hard dry facts, and makes no attempt to cultivate those very faculties which are supposed to characterise the human race; or he is so ill-prepared for his work that he fails to understand his duty. These are harsh words, but the evil is of such magnitude that it cannot be too plainly stated; those who, like myself, are brought full face to it fail in their duiy if, when opportunity occurs, they do not take occasion to call attention to its existence.

Probably the only remedy-certainly the most effectual, and that which can be most easily applied-is the introduction of a rational system of practical science teaching into all our schools, whatever their grade; one effect would be that all the school subjects would of necessity som be taught in a more scientific manner. I am not one of those who would eschew the teaching of classic;, and I do not wish to see science teaching introdtuced into schools generally, in order that the students who come to me may already have gained some knowledge of science : under existing circumstances I prefer that they shall not; but I desire its introduction because the faculty of observing and of reasoning from observation, and also from experiment, is most readily

I In my experience, the behaviour of ordinary day male students is, in this respect, particularly striking in comparison with that of female and evening students: the evening students, who come with a desire to learn, and the the opportunities afforded them. 
developed by the study of experimental science : this faculty, which is of such enormous practical value throughout life, being, I belicve-as I have said elsew here--left uncultivated after the most careful mathematical ard literary training. No one has stated this more clearly than Charles Kingsley. We are told that, speaking to the boys at Wellington College, he said: "The first thing for a boy to learn, after obedience and morality, is a habit of observation-a habit of using his eyes. It matters little what you use them on, provided you do use them. They say knowledge is power, and so it is-but only the knowledge which you get by observation. Many a man is very learned in books, and has read for years and years, and yet he is useless. He knows about all sorts of things, but he can't do them." This is precisely our complaint-the average schoolboy may know a gocd deal about things, but he can't do them. The ordinary school system of training does not, in fact, develop the "wits," to use a popular and expressive term for the observing and reasoning faculties; but it is certain that the wits require training. It is because the teaching of experimental science tends to develop the wits that those among us who know its power are so anxious for its introduction. This cannot be too clearly stated, the popular view-to judge from newspaper discussions-being apparently that science is to be classed with "extras": that it is good for those who can afford it, but can be dispensed with by those who cannot. This undoubtedly is true of the "science" which is taught the specialist, and I fear even of much of the "science" which is at present taught in schools : let us hope that ere long other views will prevail when the object which it is sought to gain by teaching science is made clear.

While blaming the schoolmaster for his neglect, it must not be forgotten that the teaching of sciences in schools meets with comparatively little encouragement at the bands of our examining bodies and the universities. Again, examinations are too often entrusted to those who have no educational experience, and with most unfortunate results : in no case, probably, is inexperience so inexcusable as in an examiner. Too often, also, the examinations are in the hands of pure specialists, who take too formal a view of their duty, and expect from boys and girls at school as much as from their own students, who are older and devote more time to the work. Such examiners are prone to discourage science by marking too severely ; and as their questions govern the teaching, instruction is given in schools without due reference to educational rcquirements, and in a purely technical style: this, I fear, is the effect of some of the universities' local examinations.

I have it on good authority, that the recent changes in the scheme of the examinations for admission at Sandhurst have forced one large school, well known for the attention paid in it to the teaching of science, to cease to give instruction in science to those of its pupils who propose to compete at these examinations, at once on their deciding to do so. Then, not only are the science scholarships at the universities few in proportion, but the great majority of students pass through their university career without being called upon to gain the slightest knowledge of physical science : yet, more of en than not, the teachers are chosen from these. A large proportion become clergymen, and considering the demands upon them and the unbounded opportunities which they have of imparting useful information, there cannot be a doubt that to no other class of the community is a knowledge of natural science likely to be of more value. ${ }^{1}$ Let us hope that the time is near when our universities will no longer be open to this reproach. ${ }^{2}$ Whatever steps they may elect to take, it is before all, things important that it be not forgotten that their main purpose must be to influence the schools, so that experimental science may be used as an educational weapon at the most appropriate time, and not when the faculties to be fashioned

\footnotetext{
x "I sometimes đream," said Kingsley, "of a day when it will be considered necessary that every candidate for ordination should be required to have passcd creditably in at least one branch of physical science, if it be only to teach him the method of sound scientific thought."

2 I learnt with the most lively satisfaction, but a few days ago, that Dr. Percival, the late head-master of Clifton College, speaking at a meeting of Convocation at Oxford last term, said: "If twenty years ago this university had said: from this time forward the elements of natural science shall take their place in responsions side by side with the elements of mathematics, and shall be equally obligatory, you would long ago have effected a revolution in shall be equally obligatory, you would long ago have effected a revolution in school education." This remark elicited some warm expressions of approval.
Dr. Percival has, I am sure, the approval of all science teachers, and he Dr. Percival has, I am sure, the approval of all science teachers, and he
will earn their gratitude, and deserve that of the public at large, if he can succeed in inducing his university to take action in accordance with his enlightened views.
}

by it have become atrophied through neglect, as I fear is too often the case, ere the university is reached.

We must carefully guard against being satisfied with the mere introduction of one or more science subjects into the school cur riculum : some of those who strenuously advocate the introduction of science teaching perhaps do not sufficiently bear this in mind. Chemistry, physics, \&c., may be-and I fear are, more often than not-taught in such a way that it were better had no attempt whatever been made to teach them. I hold that it is of no use merely to set lads to prepare oxygen, \&c., or to make experiments which please them in proportion as they more nearly resemble fireworks; and it is not the duty of the schoolmaster to train his boys as though they were to become chemists, any more than it is his duty to fit them to enter any other particular profession or trade: the whole of the science teaching in a school should be subservient to the one object of developing certain faculties. Unfortunately, two great difficulties stand in the way at present-viz, the want of suitable books and of a rational system of teaching science from the point of view here advocated ; and the requirements of the universities and other examining bodies. Both books and examinations are of too special a character: they may suit the specialist, but do not meet educational requirements. I have already somewbat fully expressed my views on this subject in a paper read at the Educational Conference in London last year. Although much more might be said, I will now only call attention to the important service which we may render in removing these difficulties.

The reform most urgently needed, in which, as members of the community, not merely as chemists, we are all most interested, is the introduction of some system which will insure a proper training for teachers. Engineers, lawyers, medical men, pharmacists, have severally associated themselves to found institutions which require those who desire to join the profession to obtain a ccrtain qualification; even chemists are seeking to do this through the Institute of Chemistry. But schoolmasters, although members of what is probally the most responsible, oncrous, useful, and honourable of any of the professions, have as yet neither made, nor shown any inclination to make, a united effort to insure that all those who join their profession shall be properly qualified. Surely the time has come when the subject must receive full public attention; the country cannot much longer remain content that the education of all but those of its sons and daughters who come within the province of the School Board should be carried on without any guarantee that it is being properly conducted.

Glaring as are the faults in the existing school system, and although it rests with the universities and other teaching and examining bodies - if the public do not intervene-to prescrite a proper course of instruction for potential schoolmasters and to enforce a rational system of training all the mental faculties, we science teachers may meanwhile do much by introducing more perfect methods into our own system of teaching. The strdents attending our courses belong to various classes: some will become chemists, and require the highest and most complete training; others will be teachers in colleges or schools; many will occupy themselves as consulting chemists or analysts; many others will have to take charge of manufacturing operations in which a knowledge of chemistry is of more or less direct importance and value; not a few will become medical men; and a large proportion, let us hope, will be those who have no direct use for chemistry, although the knowledge will be of great service to them in many ways : among such we may include architects and builders, engineers, farmers, and even country gentlemen. Have we sufficiently considered the several requirements of all these various classes? I submit, with all due deference, that we have not! Our attention has been too exclusively directed to the training up of the future analyst ; the instruction has been of too technical a character.

I know it is rank heresy to say so, but I maintain that in future far less time must be devoted to the teaching of ordinary qualitative and quantitative analysis, and that technical instruc. tion as now given in these subjects must find its place later in the course. Our main object in the first instance must be to fully develop the intellectual faculties of our students; to encourage their aspirations by inculcating broad and liberal views of our science, not an infinite number of petty details. We must not merely teach them the principles and main facts of our science, but we must show them how the knowledge of those facts and principles has been gained; and they must be so drilled as to have complete command of their knowledge. The great 
majority will not be required to perform ordinary analyses, either qualitative or quantitative; it will be sufficient for them to have gained such an amount of practical experience that they thoroughly understand the principles of analysis; that they shall have learnt to appreciate the sacredness of accuracy; and that they shall have acquired sufficient manipulative skill to be able when occasion requires to carry into execution the analytical process which their text-books tell them is applicable, and even, if necessary, to modify the process to suit circumstances.

Chemistry is no longer a purely descriptive science. The study of carbon compounds and Mendeljeff's generalisation have produced a complete revolution! The faults in our present system are precisely those which have characterised the teaching of geography and history, and which are now becoming so generally recognised and condemned; in fact, no better statement of the manner in which I conceive chemistry should be taught could be given them by broadly applying to the teaching of chemistry what was said by Professor Seeley at the International Conference on education last year, in an important paper on the teaching of history.

The necessity for some change must, I venture to think, be patent to all thoughtful teachers, and especially to those who are called upon to fulfil the painful duties of an examiner. The railway book-stalls have made us acquainted with "Confessions" of all sorts, but if the "Confessions of an Examiner" were to be written they would be far more heartrending than any. The examiner in chemistry, let him go where he will, scarcely dare to ask a question to which the answer cannot be directly read out from a text-book. He will be told "that such and such a compound is formed by the action of so and so upon so and so," but he will usually find blank ignorance of the phrase "by the action of," and as to the mode of performing the operation. The examiner would, however, be bound to agrec with the teacher that it is almost impossible to induce students to seek information outside the lecture-room, and except in the ordinary cram text-books, and that it is hopeless to expect them to devote attention to anything unless it will pay in a subsequent examination-in fact that the old university spirit of acquiring knowledge for its own sake is almost unknown among our science students. Herein lies one of the teacher's most serious difficulties, as he is more often than not bound to teach in a particular way, or to teach certain subjects, in entire opposition to his own views, in order to qualify his students to pass a particular examination ; for example, many of our colleges now distinctly state that their courses are intended to qualify students to pass the examinations of the London University, and hence they are governed by the requirements of that university, which vary more or less as the examiners are periodically changed. The examiner, on the other hand, is often placed in a difficult position : it is clear to him that the system under which the students he is called upon to examine have been taught is a bad one; yet he feels that he has no right to set questions such as he honestly believes should direct the teaching into proper channels, because he knows that the teacher is immovable, and it is not fair to make the examinees the victims of a system for which they are not responsible. Hence, perforce, the teacher goes on teaching badly and the examiner examining badly. Difficulties of this kind are bound to make themselves felt at a transition period like the present, and will only disappear if we recognise the grave responsibility which rests upon ourselves and improve our methods of teaching and our text-books : these, in too many instances, are unsuited to modern requirements, and are being made worse by stereotyping, and the practice which is gradually creeping in of merely changing the date on the title page and the numeral before the word "edition," thus engendering the belief that the information is given up to date.

Both in teaching and cxamining two important changes ought forthwith to be made : our students ought at the very beginning of their career to become familiar with the use of the balance and the imaginary distinction between so-called inorganic and organic compounds should be altogether abandoned. I do not mean that students should be taught quantitative analysis as ordinarily understood, but that instead of endeavouring to make clear to them by explanation only the meaning of terms such as equivalent, for example, we should set them to perform a. few simple quantitative exercises in determining equivalents, \&c. It can easily be done, and terms which otherwise long remain mythica. acyurre a real meaning in the student's mind. That the elements of the chemistry of carbon compounds do not find a place at a very early period in the course of instruction is one of those riddles connected with our system which it is impossible to answer. Attention was once pithily directed to the fact in my hearing by a scientific friend-not a chemist-who said he had often felt astonished that, although he had learnt a good deal of chemistry, the chemistry of the breakfast-table was practically a sealed book to him, common salt being the one object of which he felt he knew something.

I may here urge that there is one great error which we must avoid in the future, that of overworking our students, in the sense of obliging them to pay attention to too many subjects at a time. 'This is done more or less, I believe, in all our science schools, and medical students are peculiarly unfortunate in this respect. It is to some extent necessitated by the deficient preliminary education of our students; but $I$ believe that I am justified in stating that it is also partly, perhaps mainly, due to the fact that the curriculum is too often imposed by lecturers who are directly interested in the attendance of students at their lectures. This is one of the great difficulties in the way of higher education, and the continuance of the evil is probably in a measure due to inappreciation of what constitutes higher education and culture: neither consist in a smattering of knowledge of a variety of subjects such as is too often required at present.

The more general appreciation of the value of science undoubtedly depends to a considerable extent on improvements such as I have indicated being introduced. When such is the case, nwe may hope that a large number of students will enter our chemical schools, not with the intention of becoming chemists, but because it will be recognised that the training there given is of a high educational value, and that a knowledge of chemistry is of distinct service in very many avocations.

We may also hope that it will be possible ere long to teach chemistry properly to medical students. Seeing that the practice of medical men largely consists in pouring chemicals into that delicately organised vessel, the human body, and that the chemical changes which thereupon take place, or which normally and abnormally occur in it, are certainly not more simple than those which take place in ordinary inert vessels in our laboratories, the necessity for the medical man to have a knowledge of chemistry-and that no slight one-would appear to ordinary minds to stand to reason; that such is not generally acknowledged to be the case can only be accounted for by the fact that they never yet have been taught chemistry, and that the apology for chemistry which has been forced upon them has been found to be of next to no value. No proof is required that the student has ever performed a single quantitative exercise ; and $I$ have no hesitation in saying that the examinations in so-called practical chemistry, even at the London University, are beneath contempt : after more than a dozen years' experience as a teacher under the system, I can affirm that the knowledge gained is of no permanent value, and the educational discipline nil. Here the reform must be effected by the examining boards : it is for them to insist upon a satisfactory preliminary training, and they must so order their demands as to enforce a proper system of practical teaching; and if chemistry is to be of real service to medical men, more time must be devoted to its study. Physiological chemistry is taught nowhere in our country, either at the universities or at any of our great medical schools; let us hope that the publication of works like those of Gamgee and Lauder Brunton may have some effect in calling attention to this grievous neglect of so important a subject.

Having dealt with the educational aspect of the question, let me now briefly refer to some other difficulties which seriously hinder research. It has been more or less openly stated that the teachers in our chemical schools might themselves do far more. Is this the case? I do not think so; I believe it is not the staff, in most cases, who are primarily in fault. Under our peculiar system of placing the government of science schools in the hand. of those who have little, if any, experience as educationalists, and little knowledge of or sympathy with science, the appointments are sometimes made without the slightest reference to capability of inciting and conducting original investigation, and without any proof having been given either of a desire to promote higher education in the only possible way-by research; nevertheless experience shows that, as a rule, fair use is made by teachers of their opportunities. The opportunities afforded us are indeed few. In the first place, the amount of actual routine teaching we are called upon to perform is very considerable, many of us having to conduct evening as well as day classes; and the work is often of the most harassing description, owing to the want of interest 
displayed by the students. The assistance provided is also too often inadequate, and much which should be done by assistants is therefore thrown upon the principals. Higher work under these conditions is practically out of the question, not so much because it is impossible to snatch at intervals a few hours per week, but because the attention is so much taken up in the preparation of lectures and laboratory and tutorial teaching that it is impossible to secure that freedom of mind and concentrated attention which are essen tial to the successful prosecution of research. Bad, however, as is often the position of the principals, that of the junior staff is usually far worse. During official hours they are entirely occupied in tutorial work, and what little energy remains must more often than not be devoted to coaching or literary work, to supplement the too modest income which the salary attached to their official position affords. Under these circumstances, it is remarkable that so much enthusiasm should prevail among them on the subject of research. The tradition which prevails in the German schools, that the junior staff are bound to find some time for original work, is almost unknown in this country, and too often difficulties are raised, rather than facilities afforded, when the desire is manifested: we do not, in fact, sufficiently honour the assistant as the potential professor. It has also often struck me as remarkable, and it must have struck others who understand the German system, that in this practical country we have not adopted that cheap luxury-the Privat-Docent, who costs nothing and exercises a most important function in promoting higher education. The explanation of this and many other anomalies lies in the fact that very few among us realise what a university is: a clear exposition of the Scotch and German systems would be of great value in these days of new universities and university colleges.

I believe that in most, if not all, of the German chemical schools a private research assistant is placed at the disposal of the professor. Will this ever be the case here? The want material assistance is not only felt in this respect, however: few of our chemical schools are really efficiently equipped; most of them are seriously in want of larger and more expensive apparatus, of suitable specimens, \&c. ; the annual grant barely suffices for the purchase of the ordinary chemicals and the payment of unavoidable current expenses, so that, as a rule, nothing remains to meet the expenses of research work-i.e., of higher education. In point of fact, nearly all of those who are engaged in research are doing so at their own expense ; important assistance, for which we cannot be too thankful, is indeed received from the various research funds, but the proportion which the grants bear to the total sum expended is not large. I am sure we all recognise that each one of us is bound, according to his abilities and the opportunities he has, to add to the stock of knowledge, and that the keenest intellectual pleasure is derived therefrom; but it must not be forgotten that the results we obtain are very rarely of immediate practical value, and that as a rule we reap no pecuniary advantage. I venture to think, in act, that it is remarkable that so much, not that so little, is done, and that reproach rests very lightly apon the profession in this matter. Whether our national pride will prevent our being much longer beholden to foreigners for by far the greater number of new facts in chemistry is a difficult question to answer, and must rest with the public !

The occasions on which we teachers of science subjects are able to bear witness in public are of necessity few. Deeply sensible, not only of the honour, but also of the responsibility of my position as President of this Section, I felt that it was my duty to avail myself of this opportunity. Being a teacher who is interested in teaching; being convinced of the existence of most serious faults in our educational system; feeling that the present is a most critical period: I have not hesitated to speak very freely. Some of the difficulties to which I have referred might soon disappear if science teachers generally would agree to consider them together, and I believe that it would be a very great advantage if an association for the discussion of educational questions were formed of the staffs of our science colleges throughout the country. The special difficulties which surround our science colleges, and prevent them from exercising their full share of influence upon the advancement of our national prosperity might also be removed at no distant date; but I see only one way of accomplishing this, and I fear it will hardly find favour : it is by their all becoming vested in the State. In this country we like to do things in our own way, and the objection will at once be raised that this would deprive all the colleges of their individuality, and would tend to crush originality and to stereotype teaching. If I thought so I should never make the suggestion. But it would not, provided that complete academic freedom were secured to the staff, and each college were left to adjust itself to local requirements ; efficiency would be maintained by the competition of the various colleges. Local enterprise, which has hitherto been trusted to, is clearly breaking down under the tremendous strain of modern educational requirements : some change must ere long be made.

\section{(To be continued.)}

\section{SECTION C}

GEOLOGY

Opening Address by Prof. J. W. Judd, F.R.S., Sec. G.S., President of the Section.

As this city is the only place within the limits of the Scottish Highlands where our Association holds its annual gatherings, it is fitting that the attention of those who meet in this section should, on the present occasion, be specially directed to the grand problems of Highland geology. Six-and-twenty years have passed since the members of this section assembled here, under the presidency of my dear friend, my revered master, Charles Lyell. Few now present can have actually listened to the stormy discussions of that memorable occasion, but all are familiar with the nature of the problems which in the year 1859 were here so keenly debated. It is true that the fires of these controversies have now almost died out, and from their ashes have arisen the new problems which confront us to-day; but it will not, I think, be without profit to direct your attention for a few minutes to those two subjects which constituted the "burning questions" of that day-the age of the Crystalline Rocks of the Highlands, and the geological position of the Reptiliferous Sandstone of Elgin.

With respect to the first of these questions, there are especial rcasons why I should briefly review the discussions which have taken place in connection with it. It was in the meetings of this section of the British Association that the successive stages of the controversy were gradually developed. It was at a former meeting of the Association in this city that James Nicol submitted to the scientific world that splendid solution of a difficult problem, which is now universally admitted to have been the correct one. This university was, during the last twenty-seven years of his active, useful, and honoured life, the scene and centre of the labours of that profound but modest thinker to whom we owe so much. Lest it should seem presumption on my part to speak on the question, I may add that for some years before his death it was my good fortune to enjoy the friendship and confidence of the late Prof. Nicol, with whom I had several opportunities of discussing the great questions at issue between himself and Murchison. Seeing, as I do to-day, his own great claims too often forgotten or ignored, I feel that, should I, on this occasion, hold my peace-- "the very stones would cry out." It will indeed be an unfortunate day for our republic of science when the palm of recognition-withheld from him whom modesty and self-respect restrain from clamorous self-assertion-is permitted to be snatched away by the bold and noisy advertiser of his own claims.

Nearly seventy years ago, John Macculloch-that distinguished pioneer in Scottish geology-was able to prove that in our Western Highlands there exists a grand formation, made up of red sandstones and quartzite, both exhibiting unmistakable evidence of a sedimentary origin. He also pointed out that, associated with these red sandstones and quartzites, are beds of limestone, which are often altogether destitute of crystalline characters, and are sometimes bituminous, while they occasionally contain fossils.

Macculloch strongly insisted that this great system of strata, which covers large areas in Sutherland and Ross, extending also into some of the Western Isles, is distinct alike from the Oldand the New-Red Sandstone; he asserted that it belongs to a far older period than either of those formations, and, employing the phraseology of the early geologists, he gave to it the name of the "Primary Red Sandstone" (Trans. Geol. Soc. ser. I, vol. ii. p. 450, \&c. "Western Isles of Scotland" (1819), vol. ii. p. 89, \&c. "System of Geology" (1831).

Macculloch showed clearly that the strata of his "Primary Red Sandstone Formation" are often found resting unconformably upon the gneissose and schistose rocks of the Highlands; 
but that in other places they appear to be overlain conformably by, and even to alternate with, crystalline schists and gneisses. He was further able to state that the quartzites of his "Primary Red Sandstone Formation" contain organic remains, some of which he correctly identified as the burrows of marine worms, while others he recognised as Orthoceratites ("Western Isles of Scotland" (1819), vol. ii. pp. 512, 5I3). It is almost painful to have to add that his want of appreciation of the value of palæontological evidence, a weakness which Macculloch shared with so many of the early Scottish geologists, prevented any attempt on his part at the correlation of this "Primary Red Sandstone" with the rocks of other districts; and thus for more than forty years this important discovery remained almost entirely fruitless.

The next step in the history of our knowledge of these Highland strata which we have to record, was unfortunately a retrograde one. Sedgwick and Murchison, who visited the district in 1827 , maintained that Macculloch had fallen into grievous error, and that his "Primary Red Sandstone Formation" was in fact no other than an outlying part of the Old Red Sandstone (Trans. Geol. Soc. ser. 2, vol. iii. p. 155).

This view was strongly protested against by Hay Cunningham, who, writing in 1839 , after a careful survey of Sutherland, demonstrated the justice of Macculloch's conclusions, and even went beyond that geologist in showing the very intimate connection between the quartzite and limestone. He clearly illustrated by numerous sections the unconformity of the "Primary Red Sandstone Formation," consisting of red sandstone, quartzite, and limestone, upon the gneissose rocks, and the apparentiy conformable superposition to it of other schists and gneisses ("On the Geognosy of Sutherlandshire," by R. J. H. Cunningham, M.W.S. ; Transactions of the Highland and Agricultural Society of Scotland, vol. xiii. (1839).

Such was the state of geological opinion when, in the winter of 1854 , the attention of geologists was recalled to this ancient formation of Macculloch by the discovery in it of fossils by one who fully recognised their value and importance-Mr. Charles Peach. These fossils, though imperfect, were sufficient to prove that the strata containing them must be of Palaozoic age.

Three of the leaders of geological science at that day appear to have been deeply impressed with the importance of this discovery of Mr. Peach's ; but for a time, at least, the fruits of that discovery were missed, through the unfortunate retrograde teachings of Sedgwick and Murchison in I827.

Hugh Miller, whose splendid researches in the Old Red Sandstone had made him ready to welcome any extension of its boundaries, suggested that the fossils of Durness might belong to the marine Devonian.

Roderick Murchison, who in his younger days had worthily conquered a kingdom in Siluria, and by successive annexations in his later years had sought to convert this kingdom into an empire-one which should embrace all the Lower Palæozoic rocks of the globe-was not unwilling to claim his native Highlands as part of this ever-growing realm.

James Nicol, who had been the first to discover graptolites in the rocks of the Scottish Borderland, and had thus demonstrated their Silurian age, was so struck by the resemblance of some of the slaty rocks of the Highlands to the fossiliferous shales of his native district, that, ten years before Peach made his important discovery, he had suggested the probability of the Highland schists and gneisses being simply the Borderland shales and greywackes in an altered state ("Guide to the Geology of Scotland" [1844]). Hence Nicol, equally with Murchison, was prepared to accept the Silurian age of the Durness limestone, and of the rocks associated with it.

Murchison, still full of his old enthusiasm for discovery, determined to lose no time in putting to the test the truth of the suggestion made by his old friend Nicol and himself; and accordingly, shortly before the meeting of the British Association, which was fixed to take place in the year I855 at Glasgow, we find the two friends making their way into the wild district of North-west Sutherland.

Unfortunately the time was too short and the weather too unpropitious for the task they had set before themselves.

When this Geological Section assembled at Glasgow, Murchison declared his conviction that the limestone of Durness, which had yielded the fossils to Mr. Peach, was of Silurian -that is, as he employed the term-of Lower Palæozoic age. But he, at the same time, maintained the truth of his old views, that the red sandstones of Applecross and Gareloch are in reality nothing but Old Red Sandstone ("Brit. Ass. Rep." 1855); Trans. of Sec. p. 87), and in this latter contention he received the warm support of Sedgwick, who was also present at the meeting (Geikie's "Memoir of Sir Roderick Murchison" (I875), vol. ii. p. 207)

Nicol, on the other hand, appears to have been greatly dissatisfied with the results of this hasty and inauspicious journey to Sutherland. While, however, withholding his judgment as to the age of the several rock-masses, he insisted, in opposition to the views of Murchison and Sedgwick, that the whole of the vast series of Red Sandstones in Applecross and Torridon is, as Macculloch showed, inferior to the quartzite and limestone (see Nicol's "Geology of the North of Scotland" (I866), Appendix, p. 96)

In the summer of the next year, 1856 , Nicol, so soon as he was released from his teaching work in this university, hastened back to the Western Highlands to try and resolve some of the doubts which troubled him concerning the age and succession of the strata. This summer's labour was productive of great and important discoveries. In the first place, he was able to completely confirm the conclusions of Macculloch and Hay Cunningham, that all the Red Sandstone of the Western Islands, with the exception of some small patches of "New Red," belong to an old formation underlying the quartzite and limestone. But his researches also enabled him to show that Macculloch's "Primary Red Sandstone" in reality consists of two formations, the lower-to which he subsequently gave the name of the "Torridon Sandstone"-lying unconformably on the gneiss, and the upper (consisting of quarzite and limestone, containing fossils) resting everywhere unconformably upon, and overlapping, the sandstones. ${ }^{1}$ It is a very noteworthy circumstance that while Nicol admitted the accuracy of the descriptions of Macculloch and Hay Cunningham which seemed to point to a conformable superposition of beds of gneiss to the quartzite and limestone, the results of this first summer's work had already raised serious misgivings in his mind as to the correctness of this conclusion, for he wrote as follows:- "The fact of the overlying gneiss having been metamorphosed in situ, and not pushed up over the quartzite, is one requiring further investigation" (Quart. Fourn. Geol. Soc. vol. xiili, 1857 , p. 35). It is not surprising, however, to find that Nicol was so staggered by the magnitude of the faults which would be required to bring about such a result, that for more than a year he hesitated to accept this, which we now know to be the true, explanation of the phenomena.

There was a suggestion-and it was nothing more than a sug. gestion-made by Nicol at this time, which has often been very unfairly quoted to his disadvantage. Convinced that Macculloch was right as to the infraposition of the Torridon Sandstone to the quartzite and limestone, and strongly inclined to accept Murchison's confident assertion that this Torridon Sandstone was simply the "Old Red," Nicol pointed out that the only possible way of harmonising these two views was to suppose that the quartzites and limestones were of Carboniferous age; and he showed that the imperfect fossils which had been up to that time obtained at Durness were not sufficient to negative such a supposition (Quart. Four. Geol. Soc. vol, xiii., 1857, p. 36).

But during the summers of 1857 and 1858 , Nicol continued his labours in the Western Highlands, with the result of clearing away many of his difficulties and perplexities. Murchison, too, had revisited the district, and seen that his idea of the "OIdRed" age of the Torridon Sandstone would have to be finally abandoned, and that Macculloch's views, as amended by Nicol, concerning the relations of the Highland rock-masses must be accepted. Salter, too, examining more perfect specimens of fossils which had in the meanwhile been obtained from the Durness limestone by the indefatigable Mr. Charles Peach, showed that they were certainly of lower Palæozoic age (Silurian of Murchison).

The position taken up by Murchison, and on which he made his final stand, was simply arrived at by combining the stratigraphical conclusions of Macculloch and Nicol with the palæontological results of Peach and Salter.

Murchison attended the meetings of this Association at Dublin in 1857 , and at Leeds in 1858 , on both occasions making use of the opportunity for explaining in detail his ideas concerning the age and succession of the Highland rocks. On the latter

1 Colonel Sir Henry James is said to have made similar observations during the same season, the summer of 1856 , and to have communicated them to Sir Roderick Murchison by letter. But there can be no doubt that Nicol's discovery was made quite independently, and he was the first to
cublish it. publish it. 
occasion, he challenged his old friend Nicol to meet him at the forthcoming meeting at Aberdeen to discuss the question, and the challenge was accepted.

When Murchison arrived at this city, in September 1859, he brought with him a redoubtable champion in the person of Prof. (now Sir Andrew) Ramsay, the director of the Geological Survey, who had been conducted to Asiynt and shown the section there. It may perhaps serve as a caution against hasty generalisations, drawn from a single section imperfectly examined, to remember that so excellent a field-geologist as Ramsay undoubtedly was not only failed to see the weakness of Murchison's position, but threw all the weight of his great authority into the scale against $\mathrm{Nicol}$ in this memorable controversy.

Nicol, however, laid before this meeting a paper which, afterwards published in detail in the Fournal of the Geological Society, ${ }^{7}$ must be admitted to have rcally established the main facts concerning the geology of the Highlands as accepted by all geologists at the present day; though his views, as is not uncommonly the case with great and original discoveries, were met for a long time with nothing but bitter opposition or cold neglect. Permit me to state, as briefly as possible, the conclusions which Nicol, as the result of three years of patient work in the Western Highlands, was able to announce in this place, just twenty-six years ago.

I. He maintained with Macculloch and Hay Cunningham, and in opposition to the views originally propounded by Sedgwick and Murchison, that there exists in the Western Highlands an enormously thick series of red sandstones, quartzites, and limestones, which rest unconformably upon the ancient gneisses and schists, and belong to a far older geological period than the Old Red Sandstone.

2. IIe showed that this series of strata really constitutes two distinct formations, and that the older of these, the Torridon Sandstone, consists of red sandstones and conglomerates, in which no organic remains could be detected.

3. The younger of these formations was shown by him to lie unconformably upon the Torridon Sandstone, and to consist of three members, which Nicol named the Quartzitc, the Fucoid Beds, and the Limestone (Quart. Fourn. Geol. Soc, vol. xvii., I86r, p. 92, \&c.). It is this formation which has yielded the interesting fossils of Lower Palæozoic age.

4. The apparent repetition of beds of quartzite and limestone, which was insisted upon by Murchison, was shown to be due to faulting and overthrow, and thus the "Upper Quartzite" and the "Upper Limestone" of that author were proved to have no real existence (Quart. Fourn. Geol. Soc, vol. xvii., I861, pp. $98,108,109, \& c_{\text {. }}$.

5. What so many authors had taken for a conformable upward succession of this older Palæozoic formation into overlying schist and gneiss, was asserted by Nicol to be an altogether fallacious appearance, due to the thrusting of the crystalline rocks over the sedimentary ones by great overthrow-faults.

6. The relations between these crystalline and sedimentary strata in the Scottish Highlands were shown to be precisely similar to those which are constantly procluced by lateral pressure in all great mountain-chains, and consist of sharp foldings, inversions, and faulting on the very grandest scale. Lxamples of overthrow-faults, similar to those of the Scottish Highlands, were instanced by Nicol as occurring in the Alps (Quart. Fourn. Geol. Soc. vol. xvii., i861, pp. 108, 109, 110).

We cannot perhaps better illustrate the position maintained by Nicol in this remarkable paper than by quoting the following passage: "Until some rational theory is produced of the mode in which an overlying formation, hundreds of square miles in extent and thousands of feet in thickness, can have been metamorphosed, whilst the underlying formation of equal thickness and scarcely less in extent has escaped, we shall be justified in admitting inversions and extrusions" (i.e., of older masses on younger, as he explains his meaning to be) "equal to those of the Alps" (Quart. 'Foum. Geo'. Soc. vol. xvii., I86 I, p. I10).

The only serious etror into which Nicol fell-and after all it is a very inconsiderable one judged in comparison with his undoubtedly great achievements-was that of attaching too much importance to the influence of igneous intrusions in connection with the tremendous inversions and overthrow-faults to which he so clearly showed that these Highland rocks have been subjected. We now know that many of these supposed intrusive masses,

1 Quart. Journ. Geol. Soc. vol. xvii., I86s, pp. 85-113. This paper wa; read on December 5 , 1860 ; although its title is slightly diffcren;, the whule course of the argument is the same with that of the paper read here in the September of the previous year. though really of igneous origin in all probability, were of older date than the Palæozoic rocks in the midst of which they lie; and that they were brought into their present positions, not by intrusion in a liquid state, but by complicated faulting. It must be remembered that these "granulites," as Nicol very justly called them (Quart. Fourn. Geol. Soc, vol. xvii., 186r, p. 89) for they present a wonderful analogy with the typical rocks of Saxony which are known by that name, have long been regarded by geologists as among the most difficult and perplexing of rocks to explain the origin of, though the recent researches of Dr. Lehmann have now done something towards the solution of the problem.

Calmly reviewing, in the light of our present knowledge, the grand work accomplished single-handed by Nicol, I have no hesitation in asscrting that when this Association met here twenty-six ycars ago, he had already mastered the great Highland problem in all its essential details, and that his results were distinctly proclaimed during the meetings of this section.

If then, Nicol had so fully solved this great problem of Highland geology twenty-six years ago, how is it, may not unreasonably be asked, that we have waited so long for the justice of these views to be admitted?

A variety of circumstances have contributed to bring about this unfortunate result. Murchison was at the time too old and infirm to examine in careful detail the wild districts where those rock-masses are exhibited. Hence Nicol's oft-repeated invitations to view the sections in his company remained unheeded, and we find the great geologist of Aberdeen writing in 1866 his concluding plaintive words in this memorable discussion: "I must express my most sincere regret that my illustrious opponent - from whom only the most thorough conviction that my views are well founded, and that the question was one on which it became a teacher of geology in Scotland to give no uncertain utterances, could have compelled me to differ-has never found it convenient to meet me again in the North. I am convinced that we agree in so many essential points, that a few hours together in the freld would bring us nearer in opinion than whole volumes of controversy." ("Geology of the North of Scotland, p. 96.")

The phalanx of eminent geological authorities opposed to the views of Nicol, including Professors Harkness, Ramsay, Archibald Geikic, and Hull, for a long time carried all before them; but it is now admitted that each of these excellent observers was deceived by having seen only portions of the evidence, and that they based their conclusions on imperfect data. Nicol, though during the later years of his life he declined unavailing controversy, still continued to study the Highlands year by year, re. examining every joint in his armour and satisfying himself of its soundness.

In the year I877 I had an opportunity of visiting for the first time the interesting sections of Assynt and Loch Broom, in company with Dr. Taylor Smith, F.G.S., and Mr. Richard D. Oldham, now of the Geological Survey of India. Although I entered upon this task with the strongest prepossessions in favour of the Murchisonian hypothesis, yet what I saw there during several weeks of work convinced me that the theory of an "Upper Quartzite" and an "Upper Limestone" was altogether untenable, and that, so far as these two sections were concerned, Nicol's interpretation was undoubtedly the correct one. I was greatly impressed with the prools of enormous folding and faulting among these Itighland rocks, and when, shortly afterwards, 1 had an opportunity of meeting Prof. Nicol in this place, and of hearing from his lips many details of his later work, I strongly urged him to republish his conclusions with the fuller illustrations and arguments which he was then so well able to supply. To all my pleadings he made but one reply : important as he knew these discoveries to be, yet in his advancing years he thought but little of the glory of them compared to their painful consequences to himself-the breach of the old friendly relations with one he, to the end, so greatly loved and honoured. He strongly deprecated at that time the reopening of a controversy associated for him with such bitter memories; but he expressed his full conviction that when sufficiently accurate topographical maps were in existence, and the whole district should be surveyed by competent geologists, the truth of all the essential parts of his teaching would be established. ${ }^{1}$

1 In my two earlier papers "On the Secondary Rocks of Scotland," published in 1873 and 1874 respectively, I had employed the Murchisonian nomenclature for the older rocks of the Highlands whenever I bad occasion 
Most completely have these anticipations of Nicol been fulfilled. During the last seven years many of the sections of the Western Highlands have been visited by different geologists, Dr. Hicks leading the way, and not a few papers have been published embodying the results of these new studies of some of the disputed points. Such an able review of this recent work has been lately drawn up by my friend, Prof. Bonney, in his Anniversary Address to the Geological Society, that I need not go over the ground again, but will content myself by referring to that address and to two exhaustive papers read by Dr. Hicks before the Geologists' Association for full details concerning this later work. It will be seen that while new merhods of study have enabled them to improve or correct Nicol's petrological nomenclature, the principal conclusions of nearly all these writers concerning the relations of the several rock-masses entirely support his views on the subject.

But very recently Nicol's work has been tested in the way which he himself so earnestly desired. Prof. Lapworth, who, like Nicol, was especially prepared for the task by long and patient study of the crumpled Silurian rocks of the Borderland, taking advantage of the newly published Ordnance maps of Sutherland, proceeded in the summer of 1882 to Eriboll, bent on the task of unravelling the complicated rocks and of mapping them upon the large scale of 6 inches to the mile. Prof. Lapworth's detailed maps and sections were exhibited to the Geological Society on May 9, 1883, during the reading of a paper by Dr. Callaway, in which the views of Nicol also received a considerable amount of valuable support.

In the same year, 1883 , a detachment of the Geolozical Survey of Scotland, under the superintendence of Messrs. B. N. Peach and J. Horne, commenced the detailed mapping of the DurnessEriboll district. How admirably these gentlemen have performed their task we all know, and I hope that some interesting information concerning their conclusions will be laid before the present meeting. In offering them-as I am sure that I am empowered by you to do-the hearty congratulations of the Geological Section of the British Association upon the auspicious commencement of this great undertaking, I cannot refrain from reminding you that, of the leaders in this important enterprise, one is the son of the discoverer of the Durness fossils, the veteran Mr. Charles Peach to whom we owe so much, while the other is a very active and efficient local secretary of this Section.

Nor should I do justice to my own sentiments on the subject if $I$ failed to bear tribute to the judgment displayed by the present chief of the Geological Survey in his choice of a base from which to attack this difficult problem, to his loyalty in accepting results so entirely opposed to his published opinions, and to his promptitude in making his fellow-workers in geology acquainted with these important discoveries. Unfortunately called upon while still young, and with but little of that ripe experience which he has since gained, to grapple with the most intricate of problems-problems which the most practised of field-geologists might be forgiven for failing to solve-his own judgment yielded, though not without serious misgivings (see "Memoirs of Sir koderick Murchison" (1875), vol, ii. p. 238) when opposed to the ardent confidence of a companion and friend whose reputation in the scientific world commanded his respect, and whose previous achievements had won his complete reliance. If, like your own Randolph at Bannockburn, he has "lost a rose from his chaplet" at the commencement of this great Highland campaign, we are well assured that the enror will be worthily repaired in its subsequent stages.

The conclusions arrived at by Nicol, by Professor Lapworth, and by the officers of the Geological Survey, are, in all their main features, absolutely identical ; and the Murchisonian theory of Highland succession is now, by universal consent, abandoned.

In the second of the great $c$ ntroversies to which we have alluded as having occupied the attention of this Geological Section in 1859--that concerning the age and relations of the Reptiliferous Sandstone of Elgin-the combatants were found ranged in quite a different order. Nicol is seen battling shoulder to shoulder with Murchison, Ramsay, and Harkness, in favour of the Pala rzoic age of the beds in question; while Lyell, supported by Symonds of Pendock and Moore of Bath, is as stoutly maintaining their Secondary age.

The finding by Mr. Patrick Duff, in the year 1852, of the

to refer to them; but in the third of this series of papers, published in 1878 (Quart. Fourn. Geol. Soc. vol. xxxiv. p. 660), I had no hesitation in abandoning this terminology for that of Nicol. little fossil lizard called Telerpeton, and the determination of its true nature by Mantell and Owen, constitute a discovery comparable in importance and fruitfulness to Mr. Peach's detection of the fossiliferous character of the limestone of Durness ; up to that time no doubt had ever been entertained as to the "Old Red" age of the yellow sandstone of Elgin. For bringing together the remarkable fossils of these rocks, geologists are indebted to the untiring labours of Dr. Gordon of Birnie - whom, full of years and honours, and the object of such universal respect and love as indeed make grey hairs a "crown of glory," we rejoice to have still in our midst. Studying Dr. Gordon's important collections, Professor Huxley was able, shortly before the previous meeting of the Association in this city, to announce that a crocodilian (Stagonolepis), and a second lizard of Triassic affinities (Hyperodapedon), existed at the period when these beds were deposited, so that even in $\mathbf{I} 859$ the palæontological evidence in favour of the Mesozoic age of these rocks was admitted to be almost overwhelming.

But this evidence has been very greatly strengthened since that date; for Professor Huxley has shown that the genus Hyperodapedon is represented in the Trias of Warwickshire, of Devonshire, and of India. In the same reptiliferous sandstone, with its abundant footprints, the teeth of Ceratodus, a fish unknown in the Palæozoic rocks, have been found, together with the remains of a reptile which Professor Huxley permits me to state is, in his opinion, probably Dinosaurian. I am sure that you will all join with me in the hope that the health of the President of the Royal Society may soon be so far restored that he may be able to return to the examination of these fossil reptiles of Elgin, in the study of which some of the earliest of his great palzontological discoveries were achieved.

The manner in which the yellow sandstones, which have yielded these reptilian remains, are at many different points found associated with bers containing Holoptychius and other Old Red Sandstone fish, appeared to many geologists altogether inexplicable on any other hypothesis than that the strata are all of the same geological age.

In spite, however, of these appearances, and the interesting observations of Dr. Gordon and Dr. Joass on the rocks of the Tarbet peninsula, which seemed to support the hypothesis just referred to, I am able to announce that proof of the most clear and convincing character now exists of the distinction between the fish-bearing "Old Red" and the reptiliferous "New Red" of the neighbourhood of Elgin. In the year 1873 I showed that rociks, identical in character with the reptiliferous sandstone of Elgin, and the overlying calcareous and cherty rock of Stotfield, exist on the northern side of the Moray Firth, in the county of Sutherland, and that they there conformably underlie Rhætic and Liassic strata. Very recently Dr. Gordon has added a crowning discovery to his long list of previous ones, by detecting in the same quarry the rocks containing the reptilian and fish remains respectively. I find, however, that while the two series of beds present well-marked differences in their: mineral characters, the yellow sandstones with fish remains clearly overlie the undoubted Upper Old Red, and are separated from it by a well-marked bed of conglomerate. In other quarries in the district, the manner in which these two series of strata have been thrown side by side by the action of great faults is very clearly exhibited. I hope that full details of the evidence on this interesting subject will be laid before you during the present meeting.

The facts relied upon by the Palæontologist and the Stratigraphist respectively are thus found to be no longer opposed to one another. By a complicated series of parallel faults, the Devonian and Triassic sandstones, which happen to have a general resemblance in their mineral characters, are found again and again thrown side by side with one another in the Elgin district, so that the error into which geologists fell before the discovery of the distinctive fossils of the two sets of rocks, was a very pardonable one.

A retrospect of these two controversies, now so happily laid at rest, is not, I think, without its uses for the student of Highland geology, for it may serve to furnish him with some useful warnings which are in great danger of being overlooked at the present time.

The discovery of a few fossil remains in strata where they were previously unknown, has completely revolutionised our ideas concerning the age of rock-masses of enormous extent and 
thickness. Resemblances in mineral character have been proved not only to have been, at their best, very unsafe guides indeed, but to have actually betrayed those who trusted in them into the most serious errors. But for the discoveries of Charles Peach on the one hand, and of Patrick Duff and Dr. Gordon on the other, geologists would probably still continue to class the sandstones of Torridon and Elgin respectively with the "Old Red."

But perhaps the consideration of greatest importance which is impressed upon us by this retrospect is, that in these Highland districts we must be always prepared to meet with rockmasses of very different geological ages, thrown into puzzling juxtaposition by the gigantic movements to which this part of the earth's crust has been subjected. He who enters on the study of Highland geology without being prepared to encounter at every step complicated foldings, vast dislocations, and stupendous inversions of the strata, can scarcely fail to be betrayed into the most disastrous and fatal errors.

The early history of Scotland is inextricably interwoven with that of Scandinavia. This proposition, true as it is of the insignificant periods of which human history takes cognizance, applies with even greater force to the vast epochs that fall within the ken of the geologist. To us the separation of Scotland and Scandinavia is an event of very recent date indeed; it is not only an accident, but an uncompleted accident! The Scottish Highlands, with the Hebrides and Donegal on the one hand, with Orkney and Shetland on the other, must be regarded-to use a technical phrase-as mere " outliers" of the Scandinavian Peninsula.

We must acknowledge, at the outset, that the study of the geological history of this Scandinavian peninsula and its outliers is a task bristling with difficulties. The problems presented to us in our Scottish Highlands are vast, complicated, and at times seemingly insoluble. But they are precisely the same problems that confront our brother geologists in Scandinavia. And if our tasks, our doubts, our perplexities are the same, we equally share in the advantages and triumphs of discovery.

The geologists of Scandinavia-and right worthy sons of Thor they are-have the advantage of possessing a territory almost limitless in its vastness, and seemingly infinite in its variety. But the very extent of their splendid country, with its sparse population and restricted means of communication, in creases the difficulties of their task. "The harvest truly is plenteous, but the labourers are few !" With our smaller area, if we cannot expect so much variety, we may hope to gain something from the number of our students and the greater accessibility of our fields of labour.

Nor would I undervalue, in this connection, the importance of the union of this country with England. I allude, of course, not to events of yesterday, like the Accession of James VI. to the English throne and the Parliamentary Act of Union, but to operations that preceded these by many millions of years! It is no small advantage that a country like Scotland, in which the rock-formations are found hopelessly crushed and crumpled together, or broken into a thousand illfitting fragments that seem to defy all attempts to reduce them to order, should be united to one like England, where, by comparison, all is orderly and simple, the strata lying in regular sequence like well-arranged volumes in a library, and only await the touch of the geologist's hammer to display the wealth of their fossil contents.

The great Scandinavian massif, with its outlying fragments, constitutes the "basal-wreck"- -to employ Darwin's expressive term- of a great Alpine chain. On other occasions I have endeavoured to show how much our study of the nature and products of volcanic action is facilitated by the existence of similar "basal-wrecks" of volcanic mountains, like those which exist in your beautiful Western Isles. In the same way, I believe we may learn more by the stucly of this dissected mountain-chain, concerning the operations by which these grand features of our globe have originated, than by the most prolonged examination of the superficial characters of the Alps or the Himalayas.

Here the scalpel of denudation has laid bare the innermost recesses of the mountain-masses, and what we can only guess at in the Alps and the Himalayas, here stands in our own Highlands clearly revealed to view.

It is a well ascertained fact that all the existing lofty mountain-chains have been formed at a very recent geological period. The reason of this it is not difficult to divine. In the higher regions of the atmosphere, the forces of denudation work so rapidly that within a very short period-geologically speakingthe vastest mountain-chain is razed to its very foundations-

\section{" They melt like mists, the solid lands, Like clouds they shape themselves, and go !"}

It is not surprising then to find Powell and Gilbert, fresh from the study of the grand mountain-masses of the American Continent, giving expression to these thoughts in the following words: "All large mountains are young mountains, and, from the point of view of the uniformitarian, it is equally evident that all large mountains must be growing mountains; for if the process of growth is continuous, and if a high mountain melts with exceptional rapidity before the play of the elements, it is illogical to suppose that the uprising of any mountain, which to-day is lofty, has to day ceased."

The Scandinavian Alps wre a living and a growing mountainchain in the far distant Palæozoic period. Now it is not only dead, but stretched on the dissecting table of the geologist-its outer integuments and softer tissues stripped away, and its very skeleton bared to our view-a splendid "subject" for the student of mountain anatomy.

One of the first to recognise this value of our Scottish Highlands to the student of Orographic Geology was the late Daniel Sharpe. He had made himself familiar with many of the characteristic details of Alpine architecture-so far as it was then understood - and was able to show that the foliated masse s of our Highland districts exhibit precisely those relations which would be seen if the contorted and fan-like masses of the Alps were planed away by denudation. Nor in suggestions of this kind, as we have seen, was James Nicol far behind Sharpe; but at that time many of the most important features of mountain-structure were unrecognised or misinterpreted, and the conclusions of these geological pioneers were little more than guesses-though very valuable and suggestive guesses-after truth.

It is to our geological brethren over the Atlantic that we are especially indebted, not only for many important discoveries in the mechanics of mountain-formation, but for clearing away many of the clouds of error in which the subject had become in volved. To Henry Darwin Rogers, who, after a career of valuable geological work in his native State of Pennsylvania, accepted the hospitality of this country, and spent the last decade of his useful life as Professor of Natural History and Geology in the sister university of Glasgow, must be assigned the foremost place in that school of orographic geologists which has grown up in America.

The first sketch of the important theory of mountain-building to which Rogers and his fellow-geologists were led by the study of the Appalachian chain, was published in 1842 , but it was not till I 858 that the complete evidence on which this theory was founded could be published.

The conclusion at which Rogers arrived was, briefly expressed, as follows:-The Appalachian mountains were carved by denudation out of an enormously thick mass of stratified deposits, thrown into a series of parallel wave-like folds. To the westward of the mountain range " the crust-waves flatten out, recede from one another, and vanish into general horizontality; "but towards the heart of the mountain-mass the same flexed strata become greatly crowded together, their "axis-planes," become more and more inclined, till at last their folds, yielding at their apices to the tremendous lateral thrust, fractures twenty to eighty miles in length, and attender with a displacement of 20,000 feet or more, were produced.

Unfortunately Rogers accompanied these just views of mountain structure with certain crude speculations and untenable hypotheses concerning the methods by which they were produced. But in the minds of other American geologists, among whom may especially be mentioned Dana, Le Conte, and Vose--the fruitful ideas of Rogers have undergone development and expansion, while they have received abundant illustration through the labours of that active band of pioneers - the United States Gcological Survey-including Clarence King, Powell, Emmons, Hague, Dutton, Gilbert, and many others.

Nor have the brilliant results attained by these investigators in the New World been without their effect on the geologists of Europe. Lory, Suess, Heim, Baltzer, and others have shown that the clue to the right understanding of the structure of the Alps, which had been so diligently sought and so long missed by Von Buch and De Beaumont, by Studer and Favre, was now 
placed in our hands by the researches of the American geologists.

In Northern Europe, Kjerulf, Dahll, Brögger, Reusch, and other geologists have ably illustrated the same peculiarities of structure in the denuded mountain-chain near the southern extremity of which we are now assembled ; and in a recent valuable and suggestive essay "On the Secret of the Highlands" Professor Lapworth has shown how perfectly these structures are exemplified in the western district of Sutherland.

In offering a few remarks on some of the still unsolved problems of Highland geology I shall not hesitate to treat, as belonging to the same geological district, both Scandinavia and Scotland. Not only is the succession of geological deposits in the two areas almost completely identical, bul the characters of the several formations and their relations to one another in the one country are almost the exact counterpart of what they are in the other.

The problems which await solution in Scotland are the same which confront our brethren in Scandinavia; their difficulties are our difficulties, their successes our successes; if they share the benefits of our discoveries, we equally partake with them in the fruits of their achievements. Important links in the chain of geological evidence, absolutely wanting in the one area, may perchance be found in the other. Every advance, therefore, which is made in the knowledge of the rocks of the one country, must necessarily re-act upon the opinions and theories which prevail among geologists in the other.

At the base, and forming the foundation of this greatly denuded mountain-chain, there exist enormous masses of highly foliated, crystalline rocks. These, in great part at least, unclerlie the oldest known, fossiliferous strata, and are therefore of pre-Cambrian or Archran age. In spite of the labours of Kjerulf, Dahll, Brögger, Reusch, Torneböhm, and many others in Scandinavia, and of Macculloch, Nicol, and their successors in this country, much still remains to be done in studying the petrographical characters and the geognostic relations of these widespread formations.

Some thirty years ago it was suggested by Sir Roderick Murchison that among these Archæan rocks there exists a "fundamental gneiss," a formation which is the counterpart and contemporary of the rocks in Canada, to which Sir William Logan gave the name of "Laurentian." Since that time other similar attempts have been made to identify portions of these Archæan rocks in the Highlands and Scandinavia with crystalline rock-masses in different parts of the New and Old World.

I confess that, speaking for myself, I am not sanguine as to the success of such endeavours. The miserable failures which we have seen to have attended similar attempts, in the case even of far less altered rocks, where identifications have been based on mineralogical resemblances only (and in connection with which definite palæontological or stratigraphical evidence has been subsequently obtained) ought surely to teach us caution in generalising from such uncertain data. It has been argued that, where palæontological evidence is wholly wanting, and stratigraphical relations are doubtful or obscure, then we may be allowed to avail ourselves of the only data remaining to usthose derived from mincralogical resemblances. But surely, in such cases, it is wiser to admit the insufficiency of the evidence, and to say "We do not know !" rather than to construct for ourselves a "fool's paradise," with a tree of pseudo-knowledge bearing the Dead-Sea fruit of a barren terminology! The impatient student may learn with the blind poet that

$$
\text { They also serve, who only stand and wait }
$$

It is thought by some that the application of the microscope to the study of rock-masses may reveal peculiarities of structure that will serve as a substitute for palæontological evidence concerning the age of a rock when the latter is wanting. Greatly as I value the insight afforded to us by the microscope when it is applied to the study of the rocks, and highly as I esteem the opinions of some of those who hold these views, yet I fail to see that any such connection between the minute structure and the geological age of a rock has as yet been established.

Although the bold generalisation which sought to sweep all the crystalline rocks of our central Highlands into the great Silurian net has admittedly broken down, yet it by no means follows that the whole of these rock-masses are of Archæan age. Nicol always held that among the complicated foldings of the Highland rocks many portions of the older Palæozoic formations, in a highly altered condition, were included (see Quart. Journ. Geol. Soc. vol. xix. (1864); p. 184, and "Geology and Scenery of the North of Scotland," I866). The same view has been persistently maintained by Dr. Hicks, to whose researches among the more ancient rock-masses of the British Isles geologists are so greatly indebted, and also by Prof. Lapworth.

To the settlement of this very important question we may feel sure that the effort of the officers of the Geological Survey will be especially directed. The geological surveyors of Scandinavia have been so fortunate as to detect, in rocks of an extremely altered character, a number of fossils sufficiently well presersed for generic and sometimes even for specific identification. Failing the occurrence of such a fortunate accident, I confess that it has always appeared to me that the disturbances to which these Highland rocks have been subjected are so extreme, and the difficulty of making out the original planes of bedding so great, that but little can be hoped for from general sections constructed to show the relations of the rocks of the Central and Southern Grampians to the fossiliferous deposits of the North-West of Sutherland.

Lying unconformably upon these Archæan crystalline rocks in our North-West Highlands we find great masses of arkose or felspathic grit, with some conglomerates, the whole of these well-stratified deposits attaining a thickness of several thousands of feet. These rocks, in their characters and their relations, so greatly resemble the "Sparagmite Formation" of Scandinavia, that it is impossible to refrain from drawing comparisons between them. The Scandinavian formation, however, includes calcareous and slaty deposits, which are wanting in its Scottish analogue. The "Sparagmites" of Scandinavia, as a whole, appear to underlie strata containing Cambrian (Primordial) fossils, but in the very highest portion of the "Upper Sparagmite Formation" of Southern Norway there have been found, according to Kjerulf, specimens of Paradoxides.

The Scottish formation has, on the other hand, yielded no undoubted organic remains. Murchison, on the ground of its unconformable infraposition to his Silurian strata, and its resemblance to certain beds in Wales which he called Cambrian, referred it in his later years to that system. Although an identification, based on such grounds, must be admitted to be of small value indeed, yet the discovery of "Primordial" fossils in the very similar rocks of Scandinavia may be admitted to lend it some slight support. In the present state of our knowledge, however, it is surely wiser to admit that the question of the age of these beds is still an open one, and to call it by the name suggested by Nicol_-" The Torridon Sandstone." Kjerulf believes there is evidence that the Scandinavian Sparagmite, in places, passes horizontally into true gneiss, and similar appearances are not wanting in the case of our Torridon Sandstone.

( To be continued.)

NOTES FOR THE OPENING OF A DISCUSSION

ON ELECTROLYSIS, TO BE HELD IN SECTION B, AT THE BRITISH ASSOCIATION IN ABERDEEN, SEPT., I885, BY PROFESSOR OLIVER LODGE

I. WHAT is an Electrolyte? The question has two distinct meanings :

(a) Is a given substance an electrolyte at all ; i.e. when alone.

(b) Is it the electrolyte in any particular case ; i.e. when mixed with other substances.

In answering $(a)$ remember that the fact of bad conductivity does not imply that what there is is non-electrolytic. An electrolyte is one whose conduction is wholly electrolytic. Distinction between metallic and electrolytic conduction. Obedience to Ohm's law shown by elcctrolytes.

Tests of Electrolytic conduction. $\mathbf{r}$. Visible decomposition.

$$
\begin{aligned}
& \text { 2. Polarisation. } \\
& \text { 3. Non - agreement with } \\
& \text { Volta's series-law. } \\
& \text { 4. Transparency. }
\end{aligned}
$$

In answering $(b)$, the fact of bad conductivity gives a decided negative, but substances which almost insulate when alone may conduct when mixed; e.g. $\mathrm{H}_{2} \mathrm{O}+\mathrm{HCl}$.

To the question, What is the real conductor when a salt (or acid) is dissolved in water? there are four possible answers : 